\title{
Dendrite Complexity of Sympathetic Neurons Is Controlled during Postnatal Development by BMP Signaling
}

\author{
Afsaneh Majdazari, ${ }^{1}$ Jutta Stubbusch, ${ }^{1}$ Christian M. Müller, ${ }^{2}$ Melanie Hennchen, ${ }^{1}$ Marlen Weber, ${ }^{1}$ Chu-Xia Deng, ${ }^{3}$ \\ Yuji Mishina, ${ }^{4}$ Günther Schütz, ${ }^{5}$ Thomas Deller, ${ }^{2}$ and Hermann Rohrer ${ }^{1}$ \\ ${ }^{1}$ Reseach Group Developmental Neurobiology, Max-Planck-Institute for Brain Research, Frankfurt/M, Germany, ${ }^{2}$ Institute of Clinical Neuroanatomy, \\ Neuroscience Center, Goethe-University Frankfurt, Frankfurt/M, Germany, ${ }^{3}$ Genetics of Development and Disease Branch, NIDDK, NIH, Bethesda, \\ Maryland 20892, ${ }^{4}$ Department of Biologic and Materials Sciences, University of Michigan, School of Dentistry, Ann Arbor, Michigan 48109-1078, and \\ ${ }^{5}$ Department Molecular Biology of the Cell I German Cancer Research Center, D-69120 Heidelberg, Germany
}

Dendrite development is controlled by the interplay of intrinsic and extrinsic signals affecting initiation, growth, and maintenance of complex dendrites. Bone morphogenetic proteins (BMPs) stimulate dendrite growth in cultures of sympathetic, cortical, and hippocampal neurons but it was unclear whether BMPs control dendrite morphology in vivo. Using a conditional knock-out strategy to eliminate Bmprla and Smad4 in immature noradrenergic sympathetic neurons we now show that dendrite length, complexity, and neuron cell body size are reduced in adult mice deficient of Bmpr1a. The combined deletion of Bmprla and Bmpr1b causes no further decrease in dendritic features. Sympathetic neurons devoid of Bmpr1a/1b display normal Smad1/5/8 phosphorylation, which suggests that Smadindependent signaling paths are involved in dendritic growth control downstream of BMPR1A/B. Indeed, in the Smad4 conditional knock-out dendrite and cell body size are not affected and dendrite complexity and number are increased. Together, these results demonstrate an in vivo function for BMPs in the generation of mature sympathetic neuron dendrites. BMPR1 signaling controls dendrite complexity postnatally during the major dendritic growth period of sympathetic neurons.

\section{Introduction}

Dendrite size and shape influence the range of inputs a neuron can receive and are thus important for neuron function and circuit assembly. Dendrite complexity is controlled by transcription factors involved in neuron-subtype specification (Grueber et al., 2003; Gaudillière et al., 2004; Hand et al., 2005). However, dendrite development also depends on environmental signals, including members of the neurotrophin family affecting growth and branching of sympathetic (Snider, 1988) and cortical neurons (McAllister et al., 1997) and members of the bone morphogenetic protein (BMP) family controlling dendrite development in cultures of sympathetic neurons (Lein et al., 1995), hippocampal (Withers et al., 2000), cortical (Le Roux et al., 1999), and retinal ganglion cells (Hocking et al., 2008). Sympathetic neurons cultured in the presence of BMPs generate dendrites with similar numbers and branching pattern as observed in vivo (Lein et al.,

\footnotetext{
Received 0ct. 8, 2012; revised Aug. 12, 2013; accepted Aug. 12, 2013.

Author contributions: A.M., C.M.M., T.D., and H.R. designed research; A.M., J.S., C.M.M., M.H., and M.W. performed research; C.-X.D., Y.M., and G.S. contributed unpublished reagents/analytic tools; A.M., J.S., C.M.M., T.D., and H.R. analyzed data; J.S., T.D., and H.R. wrote the paper.

This work was supported by a grant from the Deutsche Forschungsgemeinschaft to H.R. (RO 2551/1.1) and T.D. (DE551/9-1). We thank Uwe Ernsberger for comments on this paper, Pamela Lein for helpful suggestions, Domenico del Turco, Mirko Schmidt, and Leslie Huber for advice, and Sabine Stanzel, Julia Andres, and Melanie Pulver for excellent technical assistance.

The authors declare no competing financial interests.

Correspondence should be addressed to Dr Hermann Rohrer, Reseach Group Developmental Neurobiology, Max-Planck-Institute for Brain Research, Deutschordenstrasse 46, Frankfurt/M, Germany. E-mail: Hermann.rohrer@brain.mpg.de.

DOI:10.1523/JNEUROSCI.4748-12.2013

Copyright $\odot 2013$ the authors $\quad 0270-6474 / 13 / 3315132-13 \$ 15.00 / 0$
}

1995) but it was unclear whether BMPs control dendrite development in vivo.

Sympathetic neurons represent a well characterized model for the in vivo analysis of dendrite development. In the rat, dendrites are generated from E14 onward and at birth the number of primary dendrites is close to adult levels (Rubin, 1985; Voyvodic, 1987). However, length and complexity of dendrites rapidly increase postnatally and are modulated up to the adult stage (Purves et al., 1987; Voyvodic, 1987; Snider, 1988). Dendrite size depends on the size of innervated target tissues (Voyvodic, 1987, 1989). Target-dependent dendrite growth is mediated both in developing and adult sympathetic ganglia by retrogradely acting nerve growth factor (NGF) (Snider, 1988; Ruit et al., 1990), which also controls synapse assembly in sympathetic dendrites (Sharma et al., 2010).

The in vitro effects of BMPs, together with their expression in sympathetic ganglion non-neuronal cells during the period of dendrite growth imply glia-derived BMPs in the control of dendrite development (Lein et al., 2002). However, as members of the TGF $\beta$ superfamily act as retrograde specification and differentiation factors for sensory and autonomic neurons (Darland and Nishi, 1998; Guha et al., 2004; Hodge et al., 2007) BMPs may also act retrogradely, synergizing with NGF in the control of dendrite complexity.

BMPs act through receptor complexes consisting of BMPRI and BMPRII/ACTRII subunits (Massagué and Wotton, 2000). BMPRIA is the major subtype expressed in sympathetic ganglia up to adult stages (Zhang et al., 1998; McPherson et al., 2000). Receptor activation results in the phosphorylation of Smad1 and 
Smad5 forming a complex with Smad4 to control BMP target gene expression. In addition, Smad4-independent, noncanonical pathways are known, conveying transcriptional and/or nontranscriptional effects (Derynck and Zhang, 2003; Moustakas and Heldin, 2005).

To address physiological functions of BMPs in dendrite development we have eliminated Bmprla or both Bmprla/1b in immature sympathetic neurons by a conditional knock-out approach. Adult sympathetic neurons display a decreased cell body size and reduced dendritic length and branch complexity. Dendrite size was unaffected and dendrite number and branching even increased in the conditional Smad 4 knock-out. These results demonstrate an essential function for BMPs in postnatal dendrite growth.

\section{Materials and Methods}

Generation of mutant mice. Mice containing deletions in Bmprla or Smad4 in sympathetic neurons were obtained by crossing conditional lines to the DbhiCre (Stanke et al., 2006; Parlato et al., 2007) mouse line. Bmprlb $b^{+/-} / B m p r 1 a^{f l / f l}$ (Yi et al., 2000; Mishina et al., 2002) were crossed with DbhiCre to obtain conditional Bmprla knock-out $\left(B m p r 1 a^{c K O}\right)$ either alone or in combination with Bmprlb-null (Bmprla $\left.a^{c K O}:: B m p r 1 b^{\Delta}\right)$. The Bmprla $a^{c K O}$ and Bmprla $a^{c K O} / 1 b^{\Delta}$ lines are in a mixed C57BL/ 6129SvEv genetic background (Yi et al., 2000; Mishina et al., 2002; Parlato et al., 2007) with low 129SvEv contribution (Y. Mishina, personal communication). Smad4 ${ }^{+/ f l}$ (Yang et al., 2002) are in a C57BL/6FVN mixed background and were repeatedly crossed with the DbhiCre line (C57BL6) (Stanke et al., 2006; Parlato et al., 2007) and maintained as $\operatorname{Smad} 4^{f l /+}:: D b h^{i \mathrm{Cre} /-}$ to reduce the FVN background contribution of the Smad4 $4^{f l+}$ mouse line (Yang et al., 2002). Smad $4^{f l f l}:: D b h^{-1-}$ controls (referred to as Smad4 $4^{f l f l}$ ) were compared with the conditional Smad4 knock-out Smad4 $4^{f l f l}:: D b h^{i C r e l-}$ (referred to as Smad4 ${ }^{c K O}$ ).

Cell culture. Superior cervical ganglia (SCGs) and stellate ganglia (STGs) were dissected from P0-P3 mice and dissociated by enzymatic treatment for $40 \mathrm{~min}$ in $18.9 \mathrm{U}$ trypsin (Invitrogen) and 22U collagenase (Cell System Biotech) per $1 \mathrm{ml}$ PBS (137 mm NaCl, $2.7 \mathrm{~mm} \mathrm{KCl,} 10 \mathrm{~mm}$ $\mathrm{Na}_{2} \mathrm{HPO}_{4} \times 2 \mathrm{H}_{2} \mathrm{O}, 2 \mathrm{mM} \mathrm{KH}_{2} \mathrm{PO}_{4}$, $\mathrm{pH}$ 7.4) followed by trituration using a siliconized, fire-polished Pasteur pipette. Cells were cultivated at a low density on poly-DL-ornithin/collagen-coated (Invitrogen/Nutacon) dishes in serum-free medium (DMEM/F12; 1:1; Sigma-Aldrich); 1\% N2supplements (Invitrogen); 1\% glutamine (Invitrogen); 1\% penicillin/streptomycin (Invitrogen); 0.1\% BSA (Sigma-Aldrich) containing $50 \mathrm{ng} / \mathrm{ml} \mathrm{NGF}$ (PeproTech; based on Higgins et al., 1991). To obtain pure neuronal cultures, $1 \mu \mathrm{M}$ cytosine- $\beta$-D-arabinofuranoside (Sigma-Aldrich) was added at $2 \mathrm{DIV}$ for $48 \mathrm{~h}$. After $72 \mathrm{~h}$ in vitro BMPs (R\&D Systems) were added at a concentration of $10 \mathrm{ng} / \mathrm{ml}$ for 2 weeks and after every medium-change (performed every third day). For Bmprla/1b and Smad4-mutant mice cultures, SCG/STG neurons from one mouse were cultivated individually, as the genotypic identification was performed after cultivation. Sympathetic neurons from one mutant mouse were distributed at equal numbers onto a BMPtreated and a control culture dish.

Immunocytochemistry. Cultured sympathetic neurons were washed with Krebs-Ringer solution before fixation with $4 \%$ paraformaldehyde (PFA; Serva) in PBS, pH 7.3. After 15 min PFA was washed off with PBS and cells were blocked with staining buffer (10\% fetal calf serum $/ 0.5 \%$ TritonX 100/PBS) for $1 \mathrm{~h}$. Subsequently, cells were incubated with MAP2-antibody (1:500; Sigma-Aldrich) in staining solution for $1 \mathrm{~h}$. Primary antibody was washed off with PBS before incubation with secondary antibody (AlexaFluor 594 anti-mouse; 1:500; Invitrogen) and DAPI. For analysis, cells were mounted with Poly-Aquamount (Polysciences) and glass coverslips.

For anti-phospho-Smad1/5/8 staining SCGs from P90 mice were dissected and embedded unfixed in TissueTek (Sakura Finetek) for cryosectioning. Twelve-micrometer sections were transferred to slides. Before staining, sections were fixed with 4\% PFA (10 min), washed with PBS three times and blocked with PBT1 (1\% BSA/0.1\% TritonX 100/PBS) for 1 h. Primary antibody (anti-P-Smad1/5/8, 1:100 in PBT1; New England
Biolabs $\mathrm{GmbH}$ ) was incubated on sections overnight at $4^{\circ} \mathrm{C}$. Unbound antibodies were washed off with PBT1. Secondary antibodies (AlexaFluor 594 anti-rabbit; 1:500; Invitrogen), together with nuclear marker DAPI, were diluted in PBT2 (0.1\% BSA/0.1\% TritonX 100/PBS) and incubated for $1 \mathrm{~h}$. Finally, sections were washed with PBS and mounted with Poly-Aquamount and glass coverslips.

In situ hybridization. To analyze the expression of noradrenergic and generic neuronal markers in SCGs and adrenal medulla of Bmpr1a- and Smad4-deficient and control mice, tissues were dissected from P90 animals and fixed in 4\% PFA overnight. After $24 \mathrm{~h}$ incubation in $30 \%$ sucrose-solution, $12 \mu \mathrm{m}$ parallel cryosections were made. Antisense, digoxigenin-labeled riboprobes for Phox $2 b, D b h, T h, S c g 10$, and Nf68 were generated by in vitro transcription according to the instructions of the manufacturer (Dig-nucleic-acid-detection-kit; Roche Diagnostics). In situ hybridization was performed as previously described (Ernsberger et al., 1997; Stanke et al., 1999).

Sympathetic ganglion size. For size analysis both SCGs were dissected from P60-P70 control and Bmprla- and Smad4-deficient mice, fixed, serially sectioned ( $12 \mu \mathrm{m}$ cryosections), and processed for dopamine- $\beta$ hydroxylase ( $D b h)$ and Scg10 in situ hybridization. On every fifth section, the stained area was imaged using a Zeiss Axiophot 2 microscope and Visitron Systems spot RT3 camera. The areas were quantified using the MetaVue (version 7.1.3.0) imaging system. The stained ganglion area was manually thresholded and quantified as square micrometer/section. The mean volume of the SCG was calculated using the Cavalieri principle (Gundersen et al., 1988). Ganglion sizes from control (Bmprla fl/fl/1 $1 b^{\Delta}$; $\left.S m a d 4^{f l / f l}\right)$ and mutant mice $\left(B m p r 1 a^{c K O} / 1 b^{\Delta}\right.$; Smad4 $\left.4^{c K O}\right)$ were quantified and statistically analyzed using unpaired $t$ test.

Analysis of dendrite morphology: in vitro. Sympathetic neurons were cultured and treated with BMPs as described above. For morphological analysis, cells were labeled with MAP2 antibodies and dendrite numbers were counted using a fluorescence microscope (Zeiss Axiophot 2). Only dendrites exceeding the length of the soma's diameter were counted, as proximal parts of the axon can also be positive for MAP2. For each culture condition, three independent experiments were conducted and dendrite numbers of at least 100 cells were counted ( $n \geq 300$ per condition). To obtain data on dendrite morphology, images with $10 \times$ magnification were taken of at least 30 cells for each condition. Dendrites were traced with the NeuroStudio-software to quantify dendritic length and the number of branch-points (Wearne et al., 2005).

Analysis of dendrite morphology: in vivo. To visualize dendrite morphology of sympathetic neurons in vivo, cells were injected with fluorescent dyes in fixed SCGs. Transgenic male mice (P3 and P90) were killed by an overdose of pentobarbital ( $400 \mathrm{mg} / \mathrm{kg}$; i.p.), perfused transcardially with PBS followed by a brief ( $\leq 2 \mathrm{~min}$ ) perfusion with $4 \% \mathrm{PFA}$ and $4 \%$ sucrose in $0.1 \mathrm{~m}$ phosphate buffer, $\mathrm{pH} 7.2$ (Pace et al., 2002). The SCGs were immediately dissected and postfixed overnight at $4^{\circ} \mathrm{C}$ in the same fixative. Fixed SCGs were embedded in $5 \%$ agarose in $1 \times$ TAE $(0.8 \mathrm{~mm}$ Tris Acetate, $0.04 \mathrm{~mm}$ EDTA, pH 8.0) and stored in PBS for a maximum period of $5 \mathrm{~d}$ at $4^{\circ} \mathrm{C}$. For microinjection, embedded SCGs were put on a custom-made submerged chamber mounted on the stage of a fixed-stage fluorescent microscope (Zeiss). Quartz glass electrodes ( $>80 \mathrm{M} \Omega$ resistance) were pulled on a horizontal electrode laser-puller (P-2000, Sutter Instruments). The electrode tips were filled with a mixture of $5 \mathrm{~mm}$ AlexaFluor 568 (potassium salt, Invitrogen) and $50 \mu \mathrm{M}$ Lucifer yellow (dilithium salt, Invitrogen) dissolved in distilled water. The rest of the electrode was filled with $0.1 \mathrm{M} \mathrm{LiCl}$ dissolved in distilled water. Using a motorized 3D-manipulator, electrodes were lowered into the tissue while negative voltage pulses $(-0.2$ to $-1 \mathrm{~V}, 1 \mathrm{~s}$ on, $1 \mathrm{~s}$ off) were applied to the electrode via a silver wire in series with a $500 \mathrm{M} \Omega$ resistor until penetration of a cell soma was observed by continuous fluorescent imaging of Lucifer yellow, thus avoiding bleaching of AlexaFluor 568 used for subsequent analysis. Fluorescent dyes were injected into the neurons by application of negative current pulses (1-5 $\mathrm{nA}$ for $10-20 \mathrm{~min}$ ) to the electrode. Intracellularly filled cells were fixed with $4 \%$ PFA overnight. For analysis, SCGs were removed from agarose, put on slides, and mounted with Aqua-Polymount and glass coverslips. Optical sections of filled cells were obtained by confocal microscopy (Zeiss LSM 510, Nikon C1) and dendrite morphology was analyzed using the ImageJ 
(http://rsbweb.nih.gov/ij/) and the NeuronStudio-PC-Programs (ns.0.9.64 CNIC). With the ImageJ program, a locally averaged stack (average of pixel values of three consecutive optical sections) was obtained and saved as TIF-format for 3D analysis. A z-projection for somasize analysis was also obtained and saved. Using the NeuronStudio software dendrites were reconstructed in the locally averaged projection images by moving in $\mathrm{z}$-direction of each optical slide and tracing one dendrite at the time. The dendrites of a reconstructed cell were labeled in centrifugal order and the labeling saved as text-format, which contains information about dendrite length, numbers, branching, and diameter. For soma-size analysis, the soma area was measured in z-projection images with the Image J program. For each transgenic mouse line, at least 40 cells from

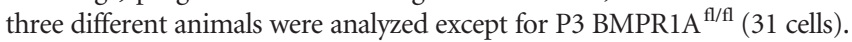
Nonparametric Mann-Whitney- $U$ test or ANOVA was used for statistical analysis as indicated.

RT PCR. RNA from E14.5, P3, and P90 SCGs and STGs of C57BL/6J mice (Charles River) was isolated using the RNeasy Kit (Qiagen) and transcribed to cDNA using the M-MLV Reverse Transcriptase Kit (Invitrogen). At E14.5, only STGs were dissected. PCR was performed using cDNA as template and Taq polymerase (Taq Polymerase Kit, Invitrogen) in a $50 \mu \mathrm{l}$ reaction (Tsarovina et al., 2004) for amplification of TGF $\beta$ family members (primers listed in Table 1). The temperature profile consisted of $30-35$ cycles $\left(95^{\circ} \mathrm{C}\right.$ for $30 \mathrm{~s}, 62-65^{\circ} \mathrm{C}$ for $30 \mathrm{~s}, 72^{\circ} \mathrm{C}$ for $30 \mathrm{~s}$ ) and a final extension at $72^{\circ} \mathrm{C}$ for 5 min. PCR products were analyzed by gel electrophoresis and ethidiumbromide staining on $2 \%$ agarose gels.

$q P C R$. RNA was used to synthesize cDNA with Oligo(dT)-primers, Random Hexamers and the Superscript-III-reverse-transcription Kit (Invitrogen). Comparative real-time qRTPCR was performed, with equal amounts of cDNA, in $200 \mu$ l nonskirted 96-well PCR plates (Thermo Scientific) using an Mx3000P PCR Real Time System (Stratagene). PCR was performed using the QuantiTect SYBR Green PCR kit (Qiagen). Each cycle consisted of denaturation for $15 \mathrm{~s}$ at $94^{\circ} \mathrm{C}$, annealing for $30 \mathrm{~s}$ at $55^{\circ} \mathrm{C}$, and extension for $30 \mathrm{~s}$ at $72^{\circ} \mathrm{C}$. QuantiTect Primer Assays (Qiagen) were used for mouse Glyceraldehyde-3-phosphate dehydrogenase (Gapdh; Mm_Gapdh_3-SG), Peptidyprolyl isomerase A (Ppia; Mm_Ppia_1-SG), tyrosine hydroxylase (Th; Mm-Th-1_SG), Dbh (Mm_Dbh_ 1_SG), SCG10 (Mm_Stmn2-1-SG), TrkA (Mm-Ntrk1_1_SG), p75 (Mm_Ngfr_1_SG), Id1 (Mm-Idb1_1_SG), and Map2 (Mm_Mtap2_1_ SG). The amplification efficiencies were determined using the MxPro software (Stratagene). At least triple PCRs of each condition were performed in parallel and data were normalized to Gapdh as reference gene. Experiments were repeated independently at least three times and expression levels of each gene in different transgenic mouse lines were compared and statistically analyzed using the efficiency corrected calculation model [Relative Expression Software Tool (REST); two-sided pairwise fixed reallocation randomization test; Pfaffl et al., 2002].

\section{Results}

Elimination of Bmprla in Dbh-

expressing immature sympathetic neurons does not affect neuron differentiation

Previous work demonstrated that BMPs are required for dendrite growth in cultures of perinatal (E20-P3) sympathetic neurons (Lein et al., 1995, 2002). The present study aims to characterize
Table 1. RT-PCR and genomic primers

\begin{tabular}{lll}
\hline Primers & Forward primer & Reverse primer \\
\hline Activin A & gag ggc tgg aag agg aaa agg aac & taa gt tgg caa agg ggc tgt g \\
Alk2 & tca gaa ccc atc cgc aag act cac & ttc cgt caa agc agc cac ttc g \\
BMP2 & acc aca cag gga cac acc & gtg cta acg aca ccc gca \\
BMP3 & agc cag ctc ttg ggt cat & atg ctc tgg atg gtg gcg \\
BMP4 & act gcc gtc gcc att cac & gcc tga tct cag cgg cat \\
BMP5 & gag cag cca gca aac gga & ggc act tcc agc tag tgg \\
BMP6 & aat ccc gag tac gtc ccc & ctg ccc ttg ctg gga atg \\
BMP7 & cag cag tga cca gag gca & cct gtg gta gct ggt agg \\
GDF1 & ggg gtc gcc gga aac att & acg gca gcc aca ctc atc \\
GDF11 & tgt ggg tgt acc ttc ggc & gca ggg ctc tct gct tac \\
TGF $\beta 1$ & gga ccg caa caa cgc cat & gct tgc gac cca cgt agt \\
TGF $\beta 2$ & cct tcg acg tga cag acg ct & gcg ggc tgg aaa aca ata cgt \\
TGF $\beta 3$ & ggc aga gtt ccg ggt ctt & aag gaa gcc tcc ctc tcg \\
GAPDH & tac ccc caa tgt gtc cgt & cta ggc ccc tcc tgt tat
\end{tabular}

BMPR1A Fx1 ggt ttg gat ctt aac ctt agg

BMPR1A Fx2 gca gct gct gct gca gec tcc

BMPR1A Fx4 tgg cta caa ttt gtc tca tgc BMPR1A exon2 aga tta ctg gga gectgt c ccc ctg ctt gag ata ctc t
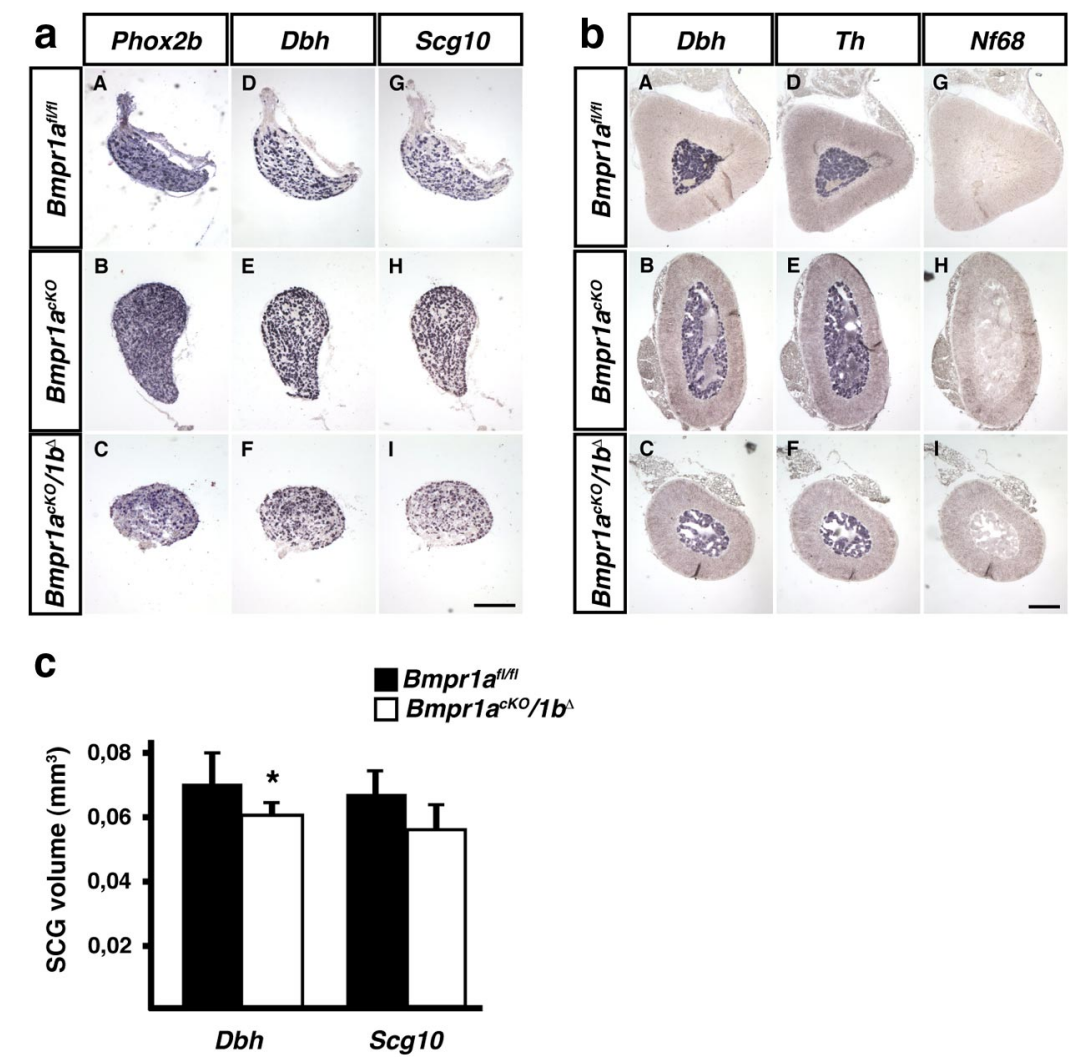

Figure 1. In situ hybridization of adrenergic and general neuronal markers in P90 SCG and adrenal medulla demonstrates normal development in Bmpr1 $a^{c K O}$ and Bmpr $1 a^{C K O} / 1 b^{\Delta}$ as compared with control Bmpr1a $a^{f l / f l}$ mice. $\boldsymbol{a}$, The noradrenergic markers Phox $2 b(\boldsymbol{a A}-\boldsymbol{a C})$ and $D b h(\boldsymbol{a D}-\boldsymbol{a F})$ show the same expression patterns in control $\left(B m p r 1 a^{f / f l}\right)$ and Bmpr1-deficient mice $\left(B m p r 1 a^{C K O} ; B m p r 1 a^{C K O} / 1 b^{\Delta}\right)$. This is also the case for the general neuronal marker $\operatorname{Scg} 10(\boldsymbol{a} \mathbf{G}-\boldsymbol{a l}) . \boldsymbol{b}$, In chromaffin cells of the adrenal medulla $D b h(\boldsymbol{b} \boldsymbol{A}-\boldsymbol{b} \mathbf{C})$ and $T h(\boldsymbol{b} \boldsymbol{D}-\boldsymbol{b} \boldsymbol{F})$ are expressed equally strong in control Bmpr $1 a^{f / f l}$ and mutant mice $\left(B m p r 1 a^{c K O}\right.$; $\left.B m p r 1 a^{c K O} / 1 b^{\Delta}\right)$. The neuronal marker Nf68 is not expressed ( $\left.\boldsymbol{b} \mathbf{G}-\boldsymbol{b} \boldsymbol{l}\right)$, as expected. $\boldsymbol{c}$, SCG size determined by quantifying the Dbhand Scg10-positive areas on serial sections. (mean \pm SD, $n=4$ for controls; $n=5$ for Bmpr1-deficient mice; unpaired $t$ test; ${ }^{*} p=$ 0.048). Calibration bar $150 \mu \mathrm{m}$.

the in vivo function of BMPs in dendrite development by blocking BMP signaling in developing sympathetic neurons. As BMPs are sufficient and essential for initial specification and differentiation of sympathetic neurons (Reissmann et al., 1996; Shah et al., 1996; Varley and Maxwell, 1996; Schneider et al., 1999; Morikawa 
a

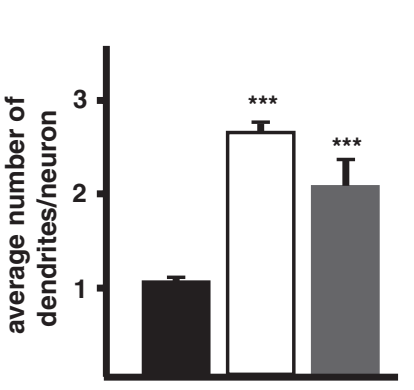

b

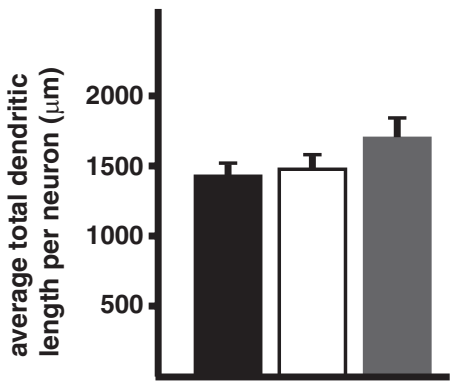

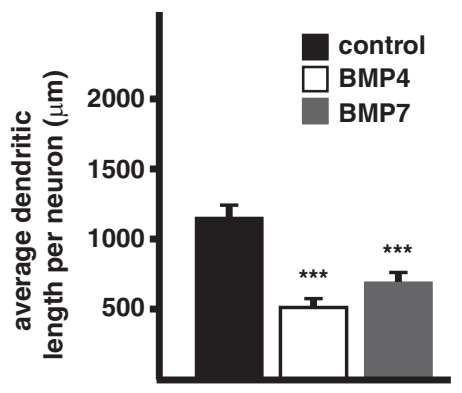

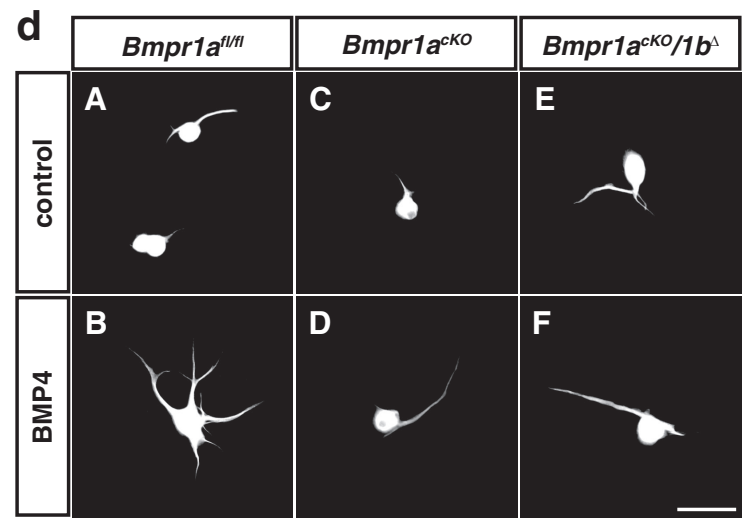

e

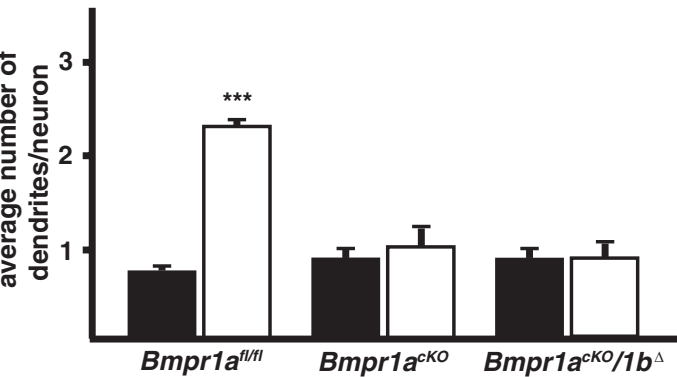

f
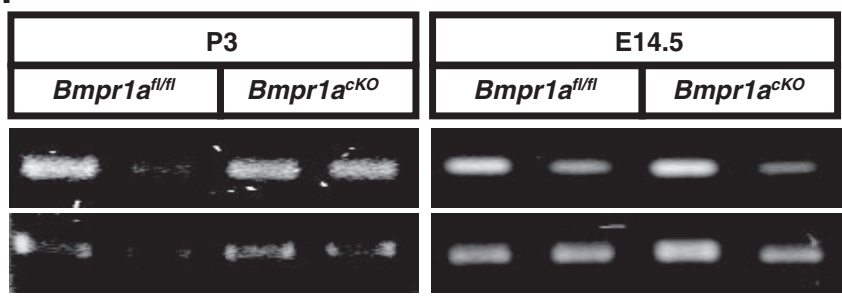

Alk2

Gapdh

Figure 2. BMP-4 and - 7 induce dendrite growth in P3 cultured sympathetic neurons through Bmpr $1 a$. $a$, In the presence of BMPs (10 ng $/ \mathrm{ml} \mathrm{BMP-4}$ white bars; $10 \mathrm{ng} / \mathrm{ml}$ BMP-7 gray bars) and 50 $\mathrm{ng} / \mathrm{ml} \mathrm{NGF}$ 2-3 dendrites are induced in neonatal (P3) cultured sympathetic neurons of wild-type (C57BL6) mice. $\boldsymbol{b}$, The addition of BMPs has no effect on the total dendrite length, whereas a significant reduction of single dendrite length is observed $(\boldsymbol{c})$. $\boldsymbol{d}$, MAP2-stained cultures demonstrate that BMP4-induced increase in dendrite number $(\boldsymbol{d} \boldsymbol{A}, \boldsymbol{d} \boldsymbol{B})$ is abolished in sympathetic neurons derived from $B m p r 1 a^{c K O}$ and $B m p r 1 a^{c K O} / 1 b^{\Delta}$ mice $(\mathbf{d D}, \mathbf{d F})$.e, Quantification of average dendrite numbers per neuron in wild-type and BMP-signaling deficient cultured sympathetic neurons. $\boldsymbol{f}$, Alk2 is expressed in wt and Bmpr $7^{\text {KKO }}$ sympathetic ganglia at P3 and E14.5 as shown by RT-PCR (different lanes represent RNA isolated from individual mice analyzed for Gapdh and Alk2). For dendrite number and length determination, at least 300 and 30 cells were analyzed, respectively. Error bars represent SEM. Statistical analysis by one-way ANOVA with Tukey-Kramer post hoc test. ${ }^{* * *} p \leq$ 0.001. Scale bar, $50 \mu \mathrm{m}$.

et al., 2009) a conditional knock-out approach was chosen, eliminating Bmprla in already differentiated noradrenergic neurons using a DbhiCre mouse line crossed with Bmprla $a^{f l f l}$ mice (Mishina et al., 2002; Bmpr1 $a^{c K O}$ ). To exclude potential compensating effects by Bmprlb, the Bmprla conditional knock-out was also investigated in Bmprlb-null (Bmprlb ${ }^{\Delta}$ ) mice (Yi et al., 2000). $B m p r 1 a^{c K O}:: B m p r 1 b^{\Delta}$ mice are referred to as $B m p r 1 a^{c K O} / 1 b^{\Delta}$.

Whereas Wnt1Cre-mediated elimination of Bmprla in neural crest cells results in a massive impairment of sympathetic neuron specification and subsequent cell death at E10.5 (Morikawa et al., 2009), sympathetic ganglia and adrenal medulla of Bmprla $a^{c K O}$ / $1 b^{\Delta}$ mice displayed normal morphology and marker gene expression (Fig. 1). SCG size was quantified from Dbh- and Scg10positive areas on serial sections and demonstrated a slight reduction by $16-17 \%$ that reached significance only for the quantification based on Dbh area (Fig. 1c). The analysis of $S c g 10$, $D b h$, and Th expression by qPCR showed no significant difference in the ratio of expression between $B m p r 1 a^{c K O} / 1 b^{\Delta}$ mutant and Bmprla $a^{f l f l} / 1 b^{\Delta /+}$ control mice [Scg10 $0.91 \pm 0.26$ (mean \pm
$\mathrm{SD} ; n=4 ; p>0.5) ; D b h 0.58 \pm 0.31($ mean $\pm \mathrm{SD} ; n=4 ; p>$ 0.05 ); Th $0.68 \pm 0.26$ (mean $\pm \mathrm{SD} ; n=4 ; p>0.1$ ); statistical analysis by REST; Pfaffl et al., 2002]. The trend to lower Dbh mRNA levels provides an explanation for apparently reduced ganglion size when $D b h$-expressing areas are quantified. Together, these results demonstrate that after the onset of $D b h$ expression (E10.5) Bmpr1 signaling has no significant effect on the maintenance of generic neuron differentiation $(\mathrm{Scg} 10)$, the expression of noradrenergic marker genes $(D b h, T h)$ and sympathetic neuron survival. Thus, $B m p r 1 a^{c K O} / 1 b^{\Delta}$ mice are suitable to study effects of BMP signaling on initial dendrite formation and the generation of dendrite complexity in sympathetic neurons.

\section{BMPR1A mediates the dendrite growth effect of BMPs in} sympathetic neuron cultures

Sympathetic neurons from postnatal rats (P3) do not develop dendrites in vitro, although dendrite growth in vivo has already been initiated in neurons from the SCG from E14 onwards (Rubin, 1985). However, in the presence of BMPs (BMP-7, 

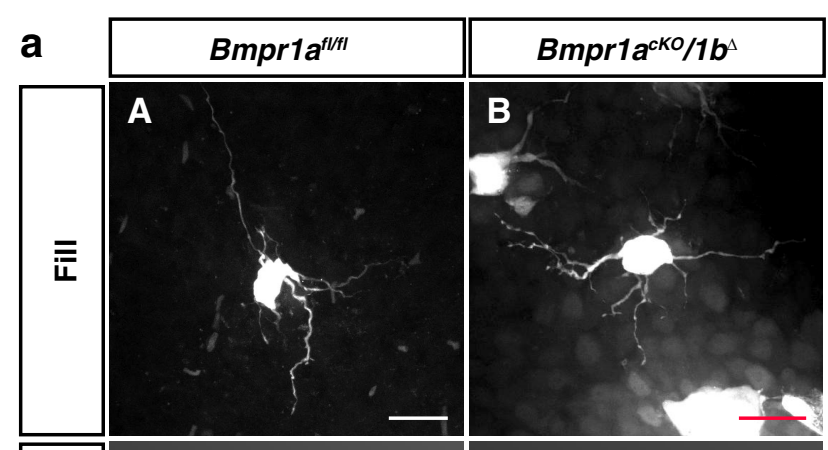

\section{f}
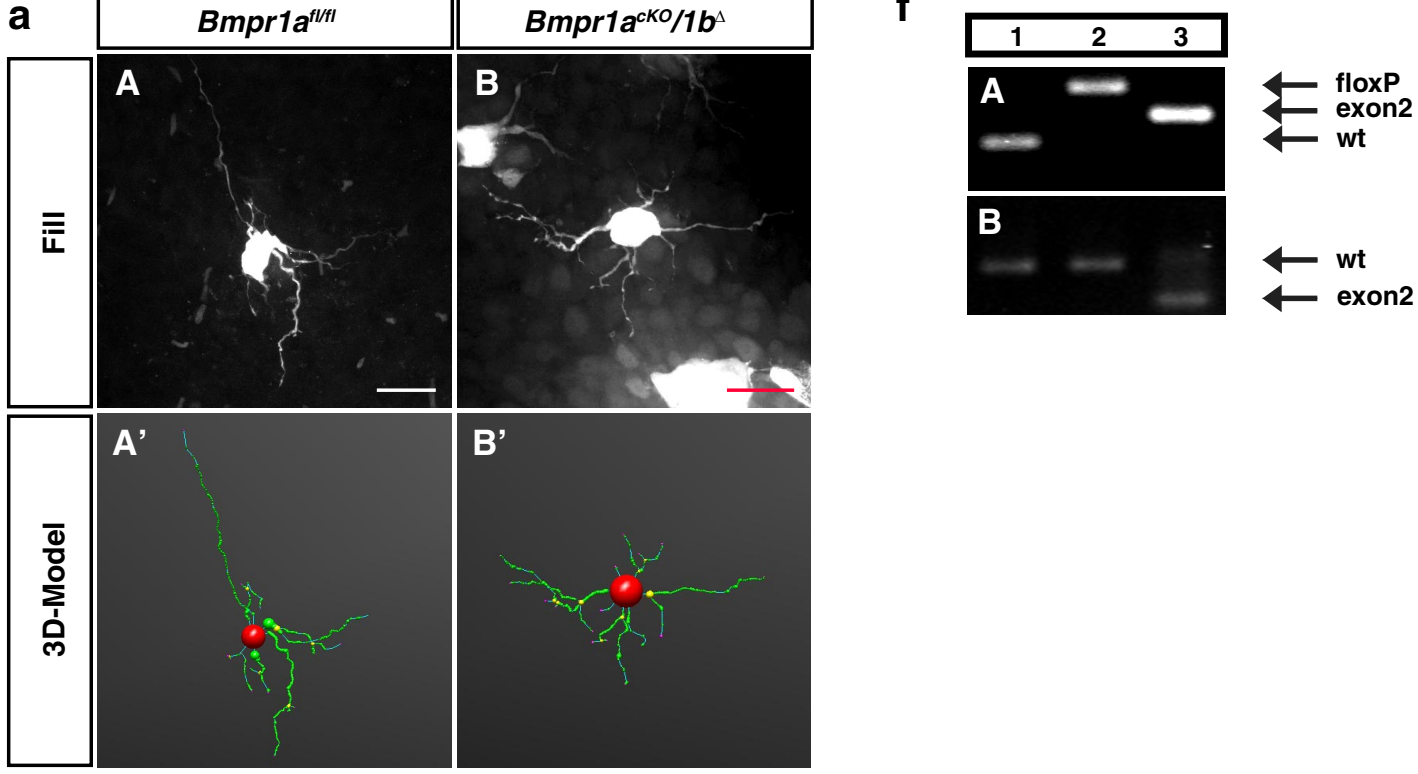

b $\quad \square^{B m p r 1 a^{A t / t}}$

C
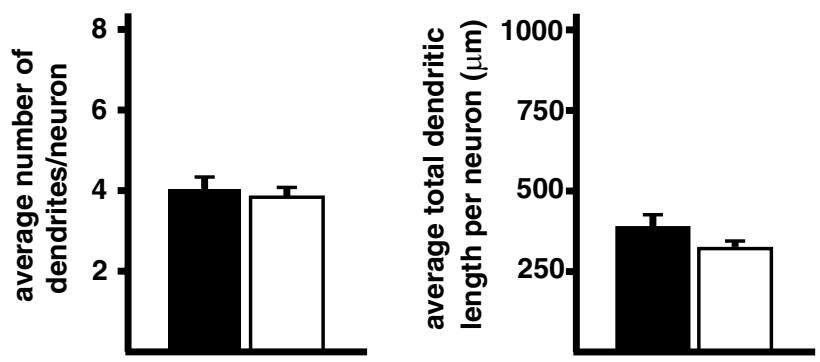

d

e
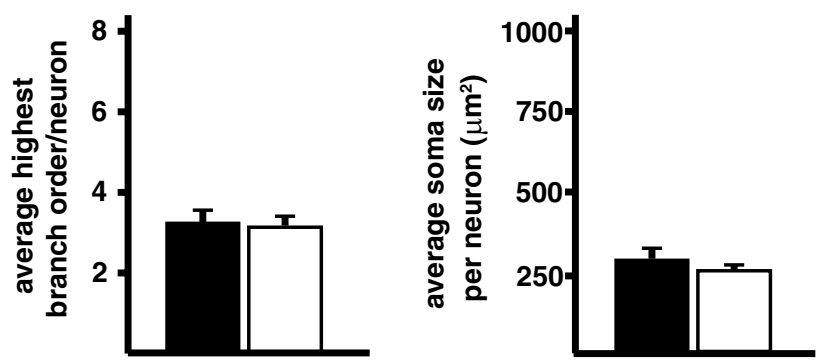

Figure 3. Dendrite morphology of $\mathrm{P} 3$ sympathetic neurons is not affected by Bmpr1 elimination in $B m p r 1 a^{c K O} / 1 b^{\Delta}$ mice. $\boldsymbol{a}$, Sympathetic neurons of fixed SCGs were individually filled with fluorescent dyes $(\boldsymbol{a A}, \boldsymbol{a} \boldsymbol{B})$ to obtain a 3D-model of the cells by confocal imaging and subsequent tracing $\left(\boldsymbol{a} \boldsymbol{A}^{\prime}, \boldsymbol{a} \boldsymbol{B}^{\prime}\right)$. Quantification of morphological parameters showed no effects on primary dendrite numbers $(\boldsymbol{b})$, total dendrite length $(\boldsymbol{c})$, number of branch points $(\boldsymbol{d})$, and soma size $(\boldsymbol{e})$. Morphological analysis was performed on 31 control and $69 \mathrm{Bmpr} 1 \mathrm{a}^{\mathrm{CKO}} / 1 b^{\Delta}$ cells. Error bars represent SEM. Statistical analysis by Mann-Whitney U test. Scale bar, $20 \mu \mathrm{m}$. $\boldsymbol{f}$, PCR on genomic DNA from E14.5 stellate ganglia shows a virtually complete elimination of exon2 in Bmpr $7 a^{c K O}$ ( $f A$, lane 3 ) as compared with wild-type $(\boldsymbol{f A}$, lane 1$)$ and Bmpr1a $a^{f / f}[$ [fA, lane 2; Bmpr1a primers: $\mathrm{Fx} 1+\mathrm{Fx} 2+\mathrm{Fx} 4$, wt; $150 \mathrm{bp}(\mathrm{Fx} 2 / \mathrm{Fx} 4)$, floxed; 230 bp (Fx2/Fx4), $\Delta$ exon2; 180 bp (Fx1/Fx4)]. Bmpr1a mRNA

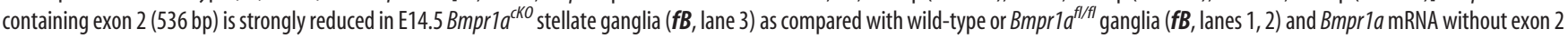
(372 bp) appears instead (fB, lane 3; Bmpr1a exon2 primers; Table 1).

BMP-5) and NGF dendrites are observed and dendrite numbers/ neuron increase during a culture period of 4 weeks to the number of dendrites present in vivo (5-7; Lein et al., 1995, 2002; Beck et al., 2001). Here, we confirm the effect of BMPs on dendrite number in cultures of postnatal mouse SCG and demonstrate similar quantitative effects by BMP-7 and BMP-4 (Fig. 2). It should be noted that for convenience we have used shorter culture periods and lower BMP levels as compared with previous studies (Lein et al., 2002). This explains, together with the lower dendrite number in mouse sympathetic neurons (four dendrites/neuron; Ruit and Snider, 1991) the quantitatively smaller effects observed compared with rat SCG cultures (Lein et al., 1995). To characterize the BMP effect in more detail, dendrite morphologies were followed by imaging, tracing, and 3D-reconstruction. Interestingly, the increase in dendrite number results in a reduced mean length of individual dendrites, suggesting a role of BMPs in dendrite 

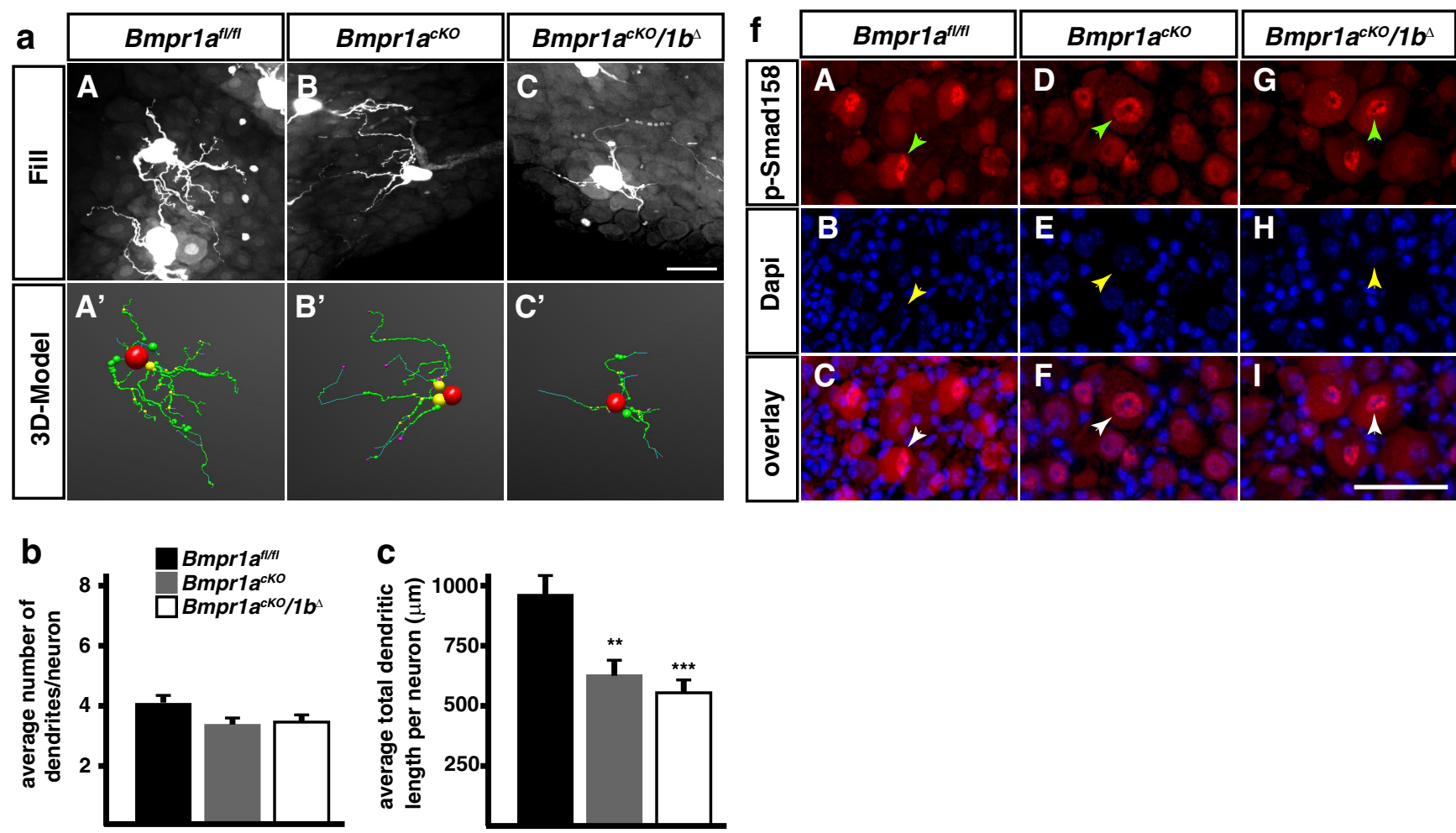

d

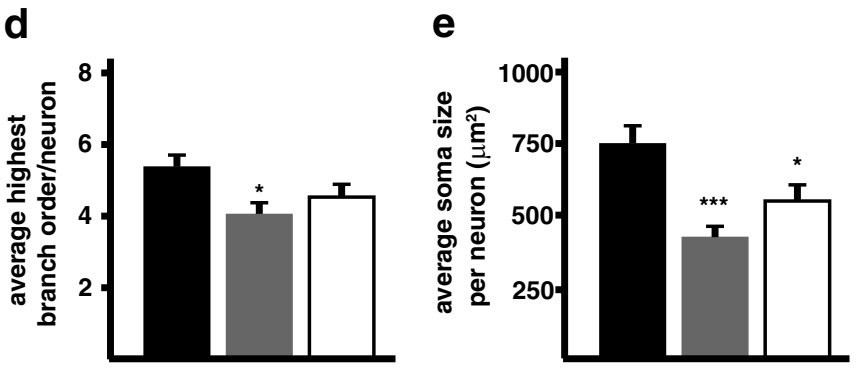

Figure 4. Dendrite morphology of sympathetic neurons is reduced in P90 Bmpr $1 a-c K O\left(B m p r 1 a^{c K 0} ; B m p r 1 a^{c K O} / 1 b^{\Delta}\right)$ mice. The reconstruction of fluorescent dye filled SCG neurons $(\boldsymbol{a})$ reveals a postnatal function of BMP-signaling in the regulation of dendrite growth in vivo. Mice deficient for BMPR1A-mediated BMP-signaling $\left(B m p r 1 a^{c K O}\right)$ have a significant reduction in the size and complexity of their dendritic trees $(\boldsymbol{c}, \boldsymbol{d})$ and soma size $(\boldsymbol{e})$ at $\mathrm{P} 90$, whereas primary dendrite numbers are not affected $(\boldsymbol{b})$. Notably, the deletion of $B m p r 1 b$ causes no further decrease of dendrite features in Bmpr $1 a^{c K O} / 1 b^{\Delta}$ compared with Bmpr $1 a^{c K O}$ mice. $f$, Cryo-sections of P90 SCGs were costained for PSmad1/5/8 and DAPI, a nuclear marker. In all three mouse lines (Bmpr $1 a^{f / f l}, B m p r 1 a^{c K O}$, and $B m p r 1 a^{c K O} / 1 b^{\Delta}$ ) cells show colocalized staining for pSmad1/5/8 and DAPI, indicating Smad-dependent nuclear transfer of activated R-Smads. Arrowheads mark pSmad1/5/8-positive large neuronal nuclei. Morphological analysis was done on 43,45 , and 41 neurons from Bmpr1 $a^{f / f l}, B m p r 1 a^{c K O} / 1 b^{\Delta}$, and $B m p r 1 a^{c K O}$, respectively and analyzed statistically by nonparametric ANOVA (Kruskal-Wallis test). Error bars represent SEM; ${ }^{*} p \leq 0.05 ;{ }^{* *} p \leq 0.01 ;{ }^{* * *} p \leq 0.001$. Scale bar, $50 \mu \mathrm{m}$.

formation/regeneration rather than in dendrite growth (at least during the 2 week culture period). An additional difference to previous studies is the similar increase in dendrite number in response to activin $\mathrm{A}$ in $\mathrm{P} 3$ mouse sympathetic neuron cultures (1.05 \pm 0.05 dendrites in control; $2.23 \pm 0.04$ dendrites in the presence of $100 \mathrm{ng} / \mathrm{ml}$ activin A; mean $\pm \mathrm{SEM} ; n=3$; ${ }^{* *} p \leq$ $0.001)$. The activin receptor Alk2 is expressed in control and Bmpr1 ${ }^{c K O}$ ganglia at E14.5 and P3 (Fig. $2 f$ ).

To investigate whether BMP signaling is blocked in sympathetic neurons of Bmprla $a^{c K O}$ and Bmprl $a^{c K O} / 1 b^{\Delta}$ mice, dendrite numbers were determined in BMP-4 treated sympathetic neuron cultures from wild-type and Bmpr1-deficient P3 SCGs (Fig. 2). As the elimination of BMPR1A and BMPR1A/1B signaling reduced dendrite numbers in BMP-4-treated cultures to control levels we concluded that the BMP effect is mediated through BMPR1A with no additional contribution from BMPR1B or Alk2. In addition, the results demonstrate that the DbhiCre-mediated recombination is complete and indicate that the conditional Bmprla knock-out is an appropriate model for the in vivo characterization of BMP functions in dendrite development.

\section{Initial growth of dendrites is not impaired in Bmpr1a a $^{c K O}$ sympathetic neurons}

The in vitro effect of BMPs on dendrite numbers in postnatal but also embryonic rat sympathetic neurons (Lein et al., 1995) suggested that BMPs are required not only for the regeneration of preformed dendrites but also for the de novo initiation of dendrites. In the DbhiCre mouse line Cre recombinase is first expressed in sympathetic ganglia at E10.5 and eliminates floxed target genes from virtually all neurons at E11.5 (Parlato et al., 2007; Tsarovina et al., 2010). Dendrite growth starts in postmitotic cells with initial dendrites generated $2 \mathrm{~d}$ after cell cycle exit (Rubin, 1985). Proliferation of Dbh-expressing neuroblasts extends in the mouse stellate ganglion up to about E18.5, with a major period of postmitotic neuron generation 


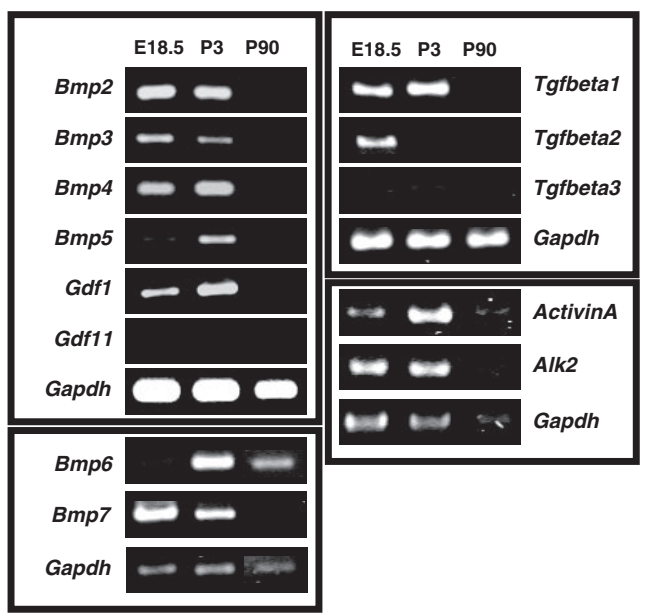

Figure 5. Expression of Tgf- $\beta$-members in sympathetic ganglia at different developmental stages. CDNA from E18.5, P3, and P90 sympathetic ganglia was analyzed for the expression of several TGF- $\beta$-members. Bmps $-2,-3,-4,-5,-7$, and Gdf1 are mainly expressed at early developmental stages (E18.5 and P3). At P90 only Bmp-2, Bmp-4, and Bmp-6 are expressed at low levels. Gdf11 is not expressed in sympathetic ganglia. In the Tgf $\beta$-group Tgf-beta 1 shows similar expression patterns as Bmps, Tgf-beta 2 is only strongly expressed at E18.5, and Tgf-beta 3 is barely detectable in sympathetic ganglia. Activin $A$ and $A / k 2$ are detectable throughout development up to adult stages. RT-PCR reactions for Bmp-6, Bmp-7, and Tgf-beta1-3 and their corresponding Gapdh reactions were analyzed on different gels and the bands assorted into Bmp-6/7 and TGF-beta1-3 subfigures.

between E12.5 and E16.5 (Callahan et al., 2008; Gonsalvez et al., 2013). Thus, it is expected that dendrites will be initiated in mouse SCG between E14.5 and E18.5, 4 d after the onset of Dbh expression. This is very similar to the scenario in the rat (Teitelman et al., 1979; Rubin, 1985; Anderson et al., 1991) and provides sufficient time between the elimination of Bmprla in proliferating DbhiCre-expressing neuroblasts and the onset of dendrite growth. When E14.5 sympathetic ganglia were analyzed for efficiency of DbhiCre to delete the Bmprla gene a virtually complete elimination of the floxed exon2 and a strong reduction in Bmprla mRNA was observed (Fig. $3 f$ ), supporting the notion that BMPR1A signaling is massively impaired already at this stage.

Dendrite morphology of sympathetic neurons was analyzed at P3 by filling individual neurons in fixed SCG with fluorescent dyes and 3D-reconstruction of the dendritic tree (for details, see Materials and Methods). Primary dendrite numbers, total dendrite length, the number of branch points and soma size were analyzed in Bmprla $a^{c K O}, B m p r 1 a^{c K O} / 1 b^{\Delta}$ and control sympathetic ganglia (Bmpr1a $a^{f l f l}$; Fig. $\left.3 a-e\right)$. Primary dendrites are operationally defined as dendritic processes that arise from the neuron cell body and extend a distance greater than the diameter of the cells (Ruit and Snider, 1991). Notably, dendrite number, complexity, total length, and soma size are neither reduced by the elimination of Bmprla nor by the conditional Bmprla/1b double-knock-out.

Bmprla is required for dendrite growth, dendrite complexity, and soma size during postnatal development

As dendrites of sympathetic neurons are generated mainly postnatally to increase their length in rat SCG from 300 to $2000 \mu \mathrm{m}$ between P0 and P90 (Voyvodic, 1987), with a similar timing in mouse SCG neurons (Ruit et al., 1990) we have characterized the effect of Bmprla/1b elimination at this point of development. Dendrite morphology was analyzed by dye filling followed by 3D reconstruction. The mean value for total dendritic length of cells
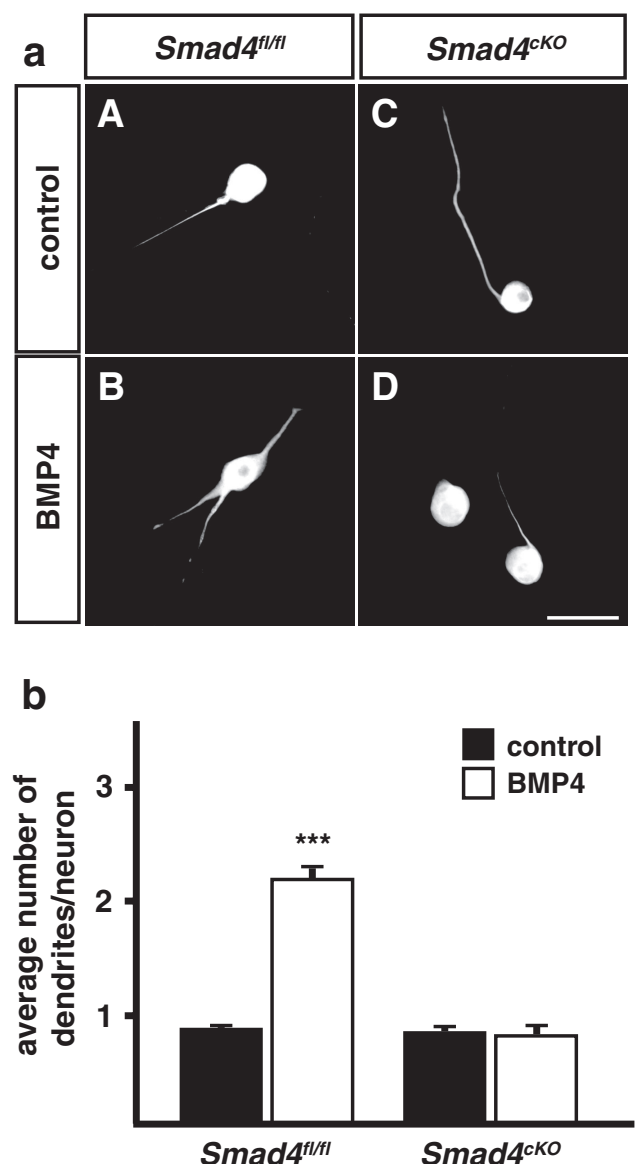

Figure 6. BMP-4 effects on dendrite growth are eliminated in cultures of P3 sympathetic neurons from Smad4 ${ }^{c K O}$ mice. $a$, Sympathetic neurons of Smad4 $4^{f l / f l}$ control and Smad4-deficient mice were cultured in the presence of $10 \mathrm{ng} / \mathrm{ml} \mathrm{BMP}-4$ for 2 weeks $(\boldsymbol{a B}, \boldsymbol{a D})$. Cells were immunolabeled for the dendrite marker MAP2 $(\boldsymbol{a A}-\boldsymbol{a D})$ to determine primary dendrite numbers per neuron. $\boldsymbol{b}$, Quantification of primary dendrite numbers in BMP4-treated and untreated sympathetic neurons of Smad4 ${ }^{f l / f l}$ and Smad $4^{c K O}$ mice revealed that BMP-induced dendrite growth depends on Smad4. At least 300 cells were analyzed per condition. Error bars represent SEM. Statistical analysis by Mann-Whitney $U$ test; ${ }^{* * *} p \leq 0.001$. Scale bar, $50 \mu \mathrm{m}$.

in controls closely matched previously published control values from cells injected with HRP in living ganglia and dye-filled cells, which implies that the dye filled the entire dendritic arbor (Yawo, 1987; Ruit et al., 1990). It should be pointed out that total dendritic length in vivo (Fig. $4 c$ ) is considerably lower than in BMPtreated sympathetic neuron cultures (Fig. $2 b$ ).

In contrast to the situation at $\mathrm{P} 3$, total length of dendrites and soma size were strongly reduced at P90 in the conditional Bmprla/1b knock-out (Fig. $4 a, c, e$ ). In addition, a significant decrease in dendrite branching was observed in the Bmpr1 $a^{c K O}$ (Fig. $4 d$ ). A decrease in soma size, number of primary dendrites, and dendrite length and complexity has been previously observed upon postnatal interference with NGF signaling (Ruit and Snider, 1991).

\section{The elimination of Bmpr1a/1b does not affect the canonical Smad4-dependent signaling pathway}

$\mathrm{BMP}$ are able to activate several distinct signal transduction pathways with a major subdivision into Smad-dependent and Smad-independent pathways (Derynck and Zhang, 2003; Chen and Panchision, 2007). As BMP effects on dendrite growth can be mediated through nontranscriptional Smad-independent activation of LIMK1 and JNK (Lee-Hoeflich et al., 2004; Podkowa 

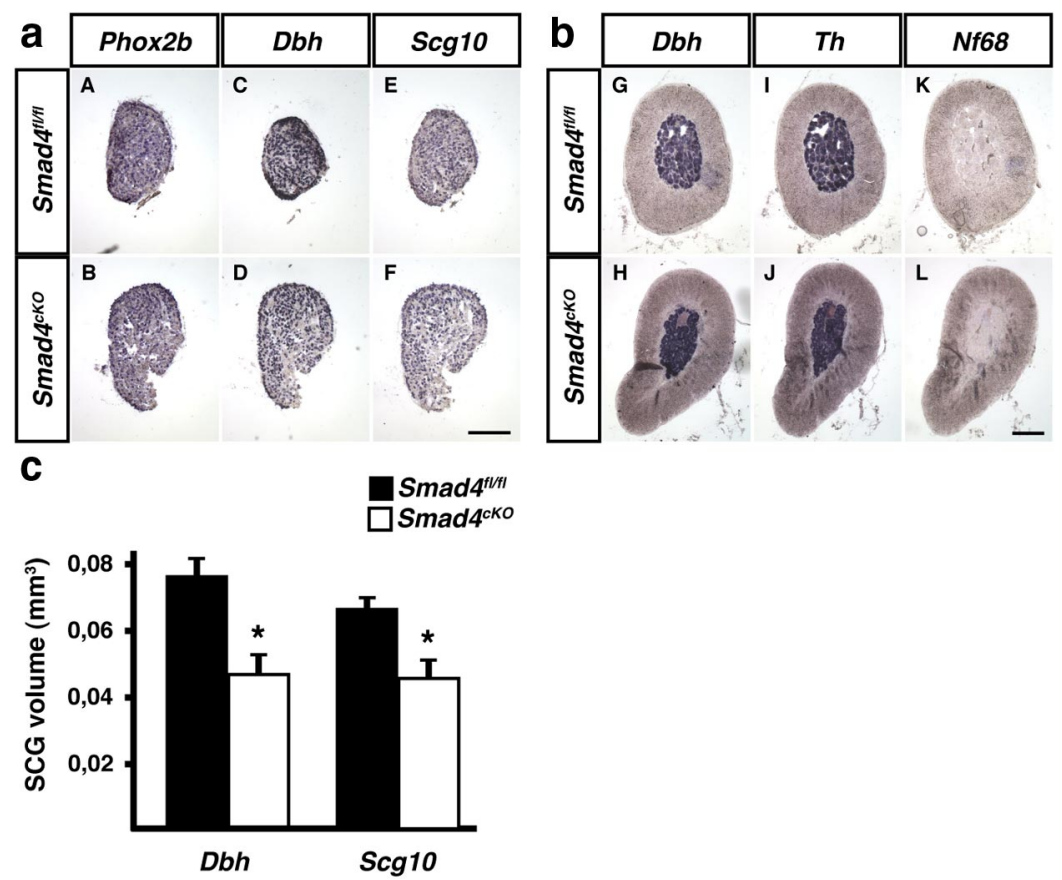

Figure 7. Marker gene expression analyzed by in situ hybridization in the SCG and adrenal medulla of P90 Smad4 ${ }^{f / f l}$ and $\mathrm{Smad}^{\mathrm{cKO}} . \boldsymbol{a}, \mathrm{SCGs}$ of Smad4-deficient mice $(\boldsymbol{a} \boldsymbol{B}, \boldsymbol{a D}, \boldsymbol{a F})$ display the same expression patterns for Phox2b, Dbh, and Scg10 as $S$ mad $4^{f / f l}$ control mice $(\boldsymbol{a A}, \boldsymbol{a C}, \boldsymbol{a} \boldsymbol{E}) \cdot \boldsymbol{b}$, The noradrenergic markers $D b h(\boldsymbol{b} G, \boldsymbol{b} \boldsymbol{H})$ and $T h(\boldsymbol{b} \mathbf{l}, \boldsymbol{b} \boldsymbol{J})$ are properly expressed in adrenal tissue of Smad4 ${ }^{f l / f l}$ and Smad $4^{c K O}$ mice. The neuronal marker $N f 68(\boldsymbol{b} \boldsymbol{K}, \boldsymbol{b} \mathbf{L})$ is not detectable in chromaffin cells of both mouse lines, as expected for neuroendocrine cells. C, SCG size determined by quantifying the Dbh-and Scg10-positive areas on serial sections. (mean $\pm S D, n=3$ for controls and for Smad4-deficient mice; unpaired $t$ test; ${ }^{*} p=0.02$ ). Scale bar, $150 \mu \mathrm{m}$.

et al., 2010) we investigated whether Smad-signaling is blocked in the absence of Bmprla/1b in sympathetic neurons. The characteristic nuclear staining for Smad1/5/8 in both control $\left(B m p r 1 a^{f l / f l}\right)$ and $B m p r 1 a^{c K O} / 1 b^{\Delta}$ adult sympathetic neurons demonstrates functional Smad-dependent signal transduction (Fig. 4). Although a small reduction in the extent of Smad1/5/8 phosphorylation cannot be excluded this result strongly implies Smad-independent BMPR1 signaling pathways in the control of dendrite growth. The maintained Smad1/5/8 phosphorylation may be explained by OP1 BMPs (BMP-5, -6, -7) acting through Alk2 rather than BMPR1A/1B or by Smad1 phosphorylation through TGF $\beta$ receptors and their ligands (for review, see Sieber et al., 2009). Tgfß1, Gdf1, ActivinA, and Alk2 are indeed expressed in sympathetic ganglia during postnatal development (Figs. 2, 5).

As Smad-dependent and -independent pathways may both contribute to various biological effects of BMPs and in some cases display redundant effects (Xu et al., 2008; Perron and Dodd, 2009), it was of interest to also investigate the effect of Smad4 elimination.

BMP-induced increase in dendrite numbers in sympathetic neuron cultures is blocked in the absence of Smad4

Sympathetic neuron cultures from P3 Smad4 ${ }^{f l f l}$ control and Smad $4^{c K O}$ mice were treated with BMP4 and analyzed for the number of $\mathrm{MAP}^{+}{ }^{+}$dendrites. In Smad4-deficient neurons BMP4 was unable to stimulate dendrite formation (Fig. 6) as observed for Bmpr1a- and Bmpr1a/1b-deficient neurons (Fig. 2), raising the question as to the in vivo role of Smad-signaling in dendrite development.

Noradrenergic and generic neuron differentiation was analyzed in the conditional Smad4 knock-out at P90, based on the expression of Phox $2 b, D b h, S c g 10$, and Nf68 in SCG and adrenal medulla (Fig. 7). The assessment of SCG size by determining the ganglion area stained for Dbh and Scg10 on serial sections revealed a reduced ganglion volume in the Smad4 ${ }^{c K O}$ (61-69\% of control; Fig. $7 c$ ). The analysis of marker gene expression by qPCR in sympathetic ganglia showed a small $(23 \%)$ Th increase in the Smad4 ${ }^{\text {cKO }}$ compared with Smad4 $4^{f l f l}$, whereas the expression ratio of $D b h$ and Scg10 were not significantly altered [ $T h$ $1.23 \pm 0.12 \%($ mean $\pm \mathrm{SD} ; n=3 ; p<$ $0.05) ; D b h 1.37 \pm 0.33$ (mean $\pm \mathrm{SD} ; n=$ $4 ; p>0.05) ; S c g 101.5 \pm 0.6($ mean \pm SD; $n=4 ; p>0,1)$; statistical analysis by REST; Pfaffl et al., 2002]. Together, only minor effects on sympathetic neuron differentiation up to the adult stage were observed in Smad4-deficient mice but ganglion size is significantly reduced.

\section{Analysis of dendrite morphology in P90 Smad4 ${ }^{\text {cKO }}$ mice}

The analysis of the conditional Smad4 knock-out was complicated by the finding that P90 sympathetic neurons in the original Smad4 $4^{f l+}$ mouse line (Yang et al., 2002) differ strongly in their morphology from neurons in other mouse lines, e.g., Bmprla $a^{f l f l}$ mice (Fig. 4), by smaller dendrite length and soma size $(550 \pm 40 \mu \mathrm{m}$ vs $961 \pm 74 \mu \mathrm{m}$ dendrite length; $396 \pm 25 \mu \mathrm{m}^{2}$ vs $749 \pm 60 \mu \mathrm{m}^{2}$ soma size), most likely due to their different genetic background (C57BL/6FVN and C57BL/6129SvEv, respectively). Genetic background mainly affects postnatal sympathetic neuron development as besides a lower number of primary dendrites in P3 $B m p r 1 a^{f l f l}$ ganglia, all other morphological parameters are identical in Bmprla $a^{f l f l}$ and the Smad4 $4^{f l++}$ mouse line (Fig. 3 and data not shown). Differences in neurite growth potential and gene expression between different mouse strains have previously been demonstrated (Dimou et al., 2006).

To minimize genetic background effects we have backcrossed Smad $4^{f l+}$ with $D b h^{i \text { Crel- }}$ (C57BL6) and analyzed the effects of Smad4 elimination by comparing Smad4 $4^{f l f l}:: D b h^{-1-}$ controls (referred to as $S m a d 4^{f l / f l}$ ) and $S m a d 4^{f l f l}:: D b h^{C r e /-}$ conditional knock-out littermates (referred to as $\mathrm{Smad} 4^{c K O}$ ). At P90 control $S m a d 4^{f l / f l}$ sympathetic neurons display similar morphological parameters as Bmpr $1 a^{f l f l}$ neurons, i.e., besides a lower total dendrite length all other parameters analyzed, soma size, highest branch order and number of primary dendrites are identical (compare Figs. 4 and 8).

The comparison of sympathetic dendrite morphologies in $S m a d 4^{c K O}$ and Smad4 $4^{f l f l}$ mice at $\mathrm{P} 90$ revealed no difference in total dendrite length and soma size (Fig. $8 a-e$ ). This is not due to incomplete Smad4-elimination as nuclear staining for $\mathrm{pSmad} 1 /$ $5 / 8$ is lost in all Smad4 ${ }^{c K O}$ sympathetic neurons, which show pSmad1/5/8 staining restricted to the cytoplasm, as expected for the absence of Smad4 (Fig. $8 f$ ).

Interestingly, dendrite branching and the number of primary dendrites were increased in the absence of Smad4, whereas both properties were reduced in the conditional Bmprla knock-out. Dendrite branching and number of primary dendrites were significantly increased as compared with both Smad4 $4^{f / f l}$ and Bmprla $a^{f l f l}$ 

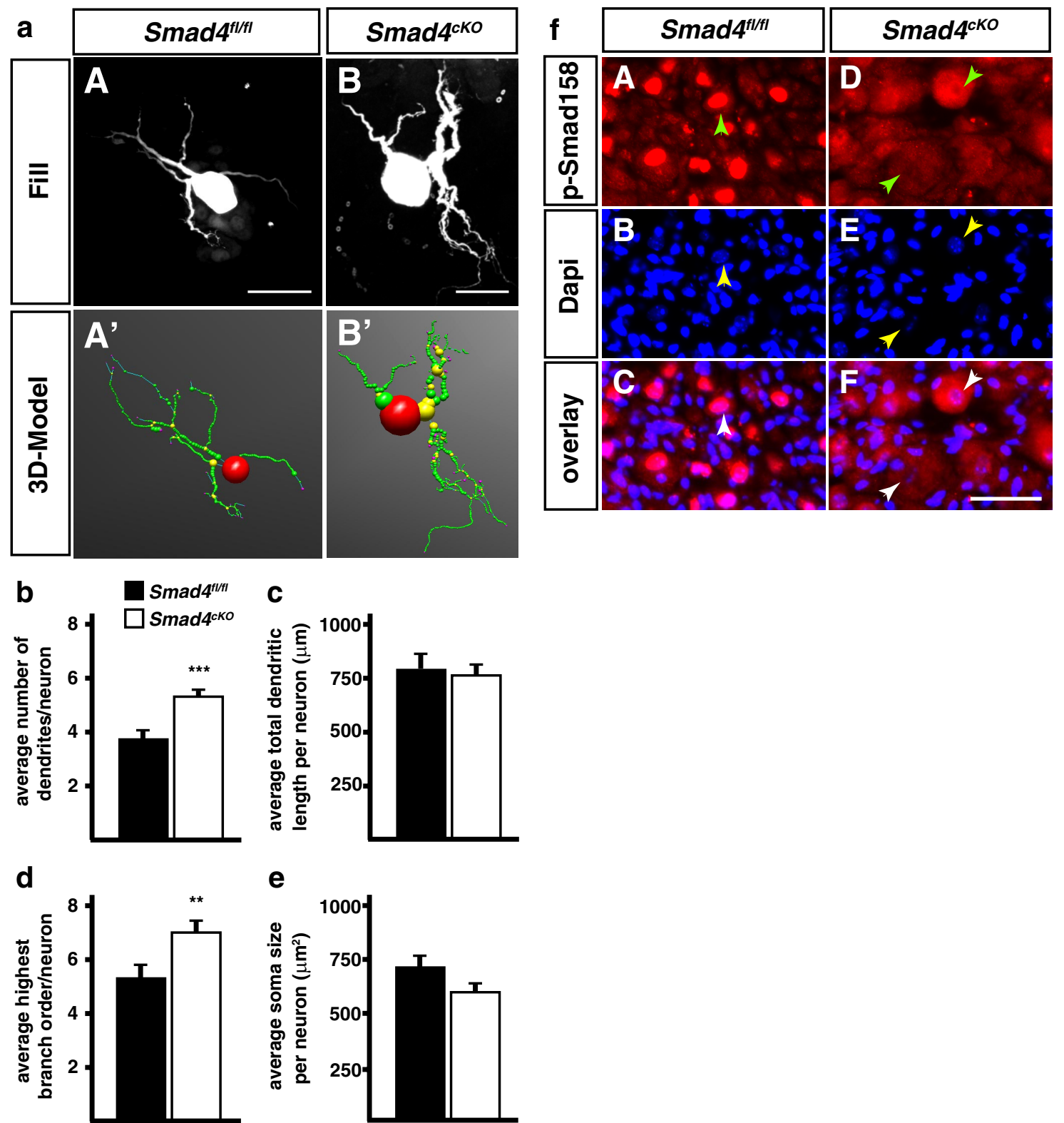

Figure 8. Dendrite morphology is altered in P90 Smad4 $4^{c K O}$ sympathetic neurons. $\boldsymbol{a}$, Sympathetic neurons from Smad4 $4^{f / f f}$ and $S \mathrm{mad} 4^{c K O}$ mice were injected with fluorescent dyes $(\boldsymbol{a A}, \boldsymbol{a} \boldsymbol{B})$ to trace dendrite morphologies. $\boldsymbol{b}, \boldsymbol{d}$, The elimination of canonical TGF- $\beta$-signaling leads to a significant increase of primary dendrite numbers and highest branching orders in $S m a d 4^{c K O}$ neurons compared with the control (Smad4 $\left.{ }^{f / f f}\right)$. Total dendritic length (c) and soma size $(\boldsymbol{e})$ are not affected in Smad4-deficient sympathetic neurons. Error bars represent SEM. Morphological analysis was done on 40

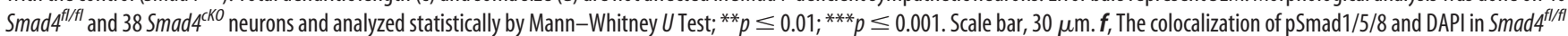
SCG neurons indicate a proper Smad4-mediated nuclear shuttling of activated R-Smads $(f A-f C)$. In Smad4-deficient $\left(S m a d{ }^{c k O}\right)$ mice phosphorylated Smads 1,5, and 8 are predominantly located in the cytosol of sympathetic neurons ( $\mathbf{f D}-\mathbf{f F}$ ). It is clearly visible that the nuclear area (fE; arrowheads) lacks pSmad1/5/8 immunoreactivity ( $\mathbf{f D}$, $\boldsymbol{f F}$ ). Arrowheads indicate the position of the cell's nucleus. Scale bar, $20 \mu \mathrm{m}$.

controls (Figs. 4, 8). Thus, as suggested by the continued Smad1/5/8 phosphorylation in the Bmprla ${ }^{c K O}$ (Fig. $4 f$ ), canonical Smaddependent signaling is not involved downstream of BMPR1A in the control of dendrite growth and may even antagonize BMPR1 effects in vivo. Our results demonstrate that dendrite growth is differentially controlled in vivo and in sympathetic neuron cultures, which includes different functions for Smad4.

Signals/mechanisms downstream of BMPR1A/1B in the control of dendrite complexity

To address the question whether Smad-independent effects of BMPR1A/1B on dendrite growth, in addition to potential nontranscriptional LIMK1 and JNK signaling also involve transcrip- tional effects we have investigated the expression of several candidate downstream targets by qPCR (Fig. 9). The decreased expression levels of $p 75$ and $I d 1$ in Bmpr1-deficient P3 sympathetic neurons demonstrate that Bmprla signaling affects the pattern of sympathetic gene expression and suggest a contribution of Smad-independent transcriptional effects to dendrite growth.

\section{Discussion}

BMPs stimulate dendrite development in cultured neurons but it was unclear whether in vivo dendrite initiation and growth are controlled by BMPs. The analysis of sympathetic neurons in mice deficient of Bmprla, Bmprla/1b, or Smad4 now demonstrates that postnatal dendritic growth is impaired in the absence of 


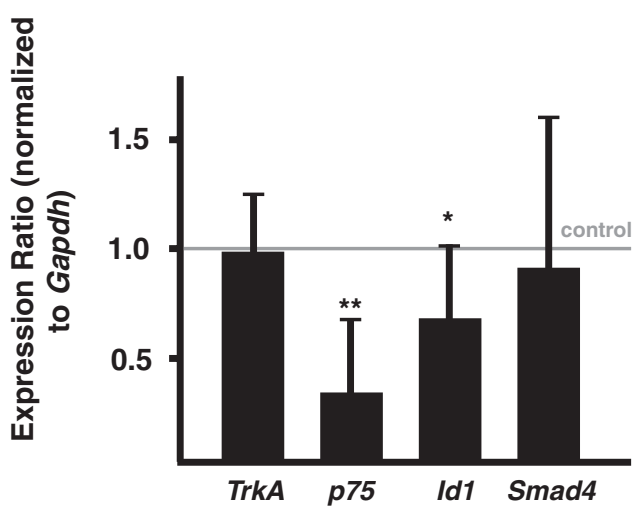

Figure 9. q $\quad$ PCR analysis in P3 Bmpr1-deficient sympathetic ganglia. The expression levels of BMP-induced genes $p 75$ and $I d 1$ (normalized to Gapdh) were investigated in Bmpr $1 a^{c K O} / 1 b^{\Delta}$ compared with controls (Bmpr $1 a^{f l / f l}$; indicated by line), showing a significant reduction of $p 75$ and Id1. Expression of TrkA and Smad4 is not influenced by elimination of BMP-signaling. Similar results were obtained upon normalization to Ppia (mean $\pm S D ; n=8$; statistical analysis by relative expression software REST; ${ }^{*} p \leq 0.05 ;{ }^{* *} p \leq 0.01$ ).

Bmprla/1b, resulting in reduced total dendrite length, branching, and cell body size. Bmprla/1b effects are mediated by Smad4independent signaling.

\section{Embryonic growth of dendrites is not impaired in $B m p r 1 a^{c K O}$ sympathetic neurons}

The increase in dendrite number elicited by BMP4 and BMP7 in mouse SCG cultures was completely blocked in neurons deficient of Bmprla and Smad4, which is in agreement with previous experiments using dominant-negative Bmprla and Smad1 to block the effect of BMP5 and BMP7 on dendrite growth, respectively (Beck et al., 2001; Guo et al., 2001). A single MAP2 ${ }^{+}$dendrite was present in control cultures and, as the multiple dendrites extended in the presence of BMPs were considerably shorter, total dendrite length did not increase in the presence of BMPs. It is likely, however, that longer culture periods and higher BMP levels would lead to a net increase in dendrite length as observed in rat neuron cultures (Lein et al., 1995).

In vivo, dendrite number and morphology were not impaired in P3 Bmpr1 $a^{c K O}$ neurons. The DbhiCre mouse line efficiently eliminates floxed target genes at E11.5 (Parlato et al., 2007; Tsarovina et al., 2010). In addition, exon2 of the Bmpr1a gene is virtually completely deleted in E14.5 ganglia, resulting in a strong reduction of Bmprla mRNA. Residual Bmprla mRNA may be explained by the presence of non-neuronal cells not affected by DbhiCre or by slow turnover of Bmprla mRNA. These findings imply a major reduction in BMPR1A signaling before the first primary dendrites are generated and thus argue against a function of BMPR1A/1B in dendrite initiation. However, as dendrite formation may involve redundant actions of several TGF $\beta$ ligands acting through different receptors (Hocking et al., 2008) a role of TGF $\beta$ family members is not excluded. Activin A is a potential candidate, which stimulates dendrite development in vitro, is expressed in sympathetic ganglia and acts via ACTR1B and Smad2/3.

In vitro studies involving BMP treatment or cocultures with BMP-producing cells (Lein et al., 2002) represent gain-offunction experiments that reveal a potential that seems not to be realized in vivo. Notably, dendrites reach bigger size in vitro as in vivo, implying inhibitory signals in vivo that are not present in sympathetic neuron cultures.

\section{Bmpr1a/1b is involved in the control of postnatal dendrite growth}

Mature neuron morphology was analyzed in P90 SCG by dye filling and 3D-reconstruction. The values for total dendritic length, neuron cell body size and number of primary dendrites agree with previous dye injection results and data from HRP injections in live ganglia (Yawo, 1987; Ruit et al., 1990). In $B m p r 1 a^{c K O}$ sympathetic neurons total dendritic length, cell body size, and dendritic complexity is significantly reduced, whereas the expression of noradrenergic and generic neuronal marker genes are not altered. Effects were not enhanced in the Bmpr1a/1b double knock-out, which implies that Bmprlb does not compensate for the lack of Bmprla. As dendritic parameters were unchanged in the absence of Bmpr1a/1b at P3 but decreased at P90, we conclude that Bmprla/1b signaling contributes to postnatal dendritic growth.

A Smad-independent signaling path is implied downstream of BMPR1A/1B as nuclear pSmad1/5/8 staining was observed in Bmpr1a/1b-deficient neurons. Notably, also the initial BMPinduced differentiation of sympathetic neurons depends on Smad-independent Bmprla pathways (Büchmann-Møller et al., 2009; Morikawa et al., 2009). However, whereas sympathetic neuron development is completely blocked in the Wnt1Cremediated Bmprla knock-out, we observed only a partial inhibition of dendrite development in the DbhiCre-mediated Bmprla/ $1 b$ knock-out. This may be explained by residual BMP-signaling through the ALK2 receptor, which is activated by BMP5, -6, and -7 (ten Dijke and Hill, 2004). However, BMP5 effects on dendrite formation in sympathetic neuron cultures were completely blocked by interfering with BMPR1A (Beck et al., 2001), suggesting that ALK2 cannot replace BMPR1A in sympathetic neurons. Residual postnatal dendritic growth in the $B m p r 1 a^{c K O} / 1 b^{\Delta}$ neurons may also be explained by the function of additional TGF $\beta$ / BMP family members. In the retina dendrite development was inhibited only by the combined knockdown of BMP and Activin signaling (Hocking et al., 2008). Considering the multitude of signals influencing dendritic growth in vivo (Lom and CohenCory, 1999; Yu and Malenka, 2003; Fenstermaker et al., 2004; Gascon et al., 2006), it is likely that BMPR1 signaling is not the only factor controlling dendritic growth in sympathetic neurons.

\section{Different effects of Smad4- and Bmpr1a-knock-out on dendritic growth}

The elimination of Smad4 resulted in increased dendritic branching and dendrite number. As ganglion size is reduced, the most straightforward explanation is that the residual neurons receive increased amounts of target-derived NGF, resulting in increased dendrite numbers and TH expression (Otten et al., 1977; Ruit et al., 1990; Ruit and Snider, 1991; Brodski et al., 2002). An alternative explanation is that Smad4 acts in vivo as a brake on dendritic branching and primary dendrite maintenance, which is removed in the conditional knock-out. There is a complex signaling crosstalk between BMPs and pathways of MAPK, Wnt, and interleukin-6 cytokines including antagonistic functions in specific cellular contexts (Lein et al., 2007; Guo and Wang, 2009). Smad4 signaling may in vivo control the expression of factors that negatively control dendrite branching (e.g., IL-6 cytokines; Guo et al., 1999) or interfere with the expression of growth stimulatory signals like Wnt/ $\beta$-catenin (Yu and Malenka, 2003; Rosso et al., 2005). 


\section{Smad-independent signaling and downstream targets in the control of dendritic growth}

The Smad-independent function of Bmpr1a/1b may either involve transcriptional effects through activation of the extracellular signal-regulated protein kinase (ERK), p38 mitogen-activated protein kinase (p38), c-Jun N-terminal kinase (JNK), phosphatitylinositol 3-kinase (PI3K), or nontranscriptional effects by activating Rho-like GTPase signaling pathways or LIMK1 and JNK (Moustakas and Heldin, 2005; Kang et al., 2009; Zhang, 2009). Both PKA and Erk-MAPK are essential signals downstream of BMPs in several cellular contexts (Jun et al., 2010; Chiu et al., 2012), including neural crest cells that differentiate in vitro to noradrenergic neurons (Liu et al., 2005), and are thus implicated also in vivo in the initial Smad-independent sympathetic neuron differentiation (Büchmann-Møller et al., 2009; Morikawa et al., 2009). The finding that ERK inhibition in sympathetic neuron cultures stimulates BMP-induced dendritic growth argues, however, against a major role of ERK activation in the BMPdependent control of dendritic length (Kim et al., 2004). The reduced expression of $p 75$ in $\mathrm{P} 3 \mathrm{Bmpr} 1 \mathrm{a}^{c K O}$ sympathetic neurons is of particular interest as transcript levels are also upregulated by BMPs in cultured sympathetic neurons (Garred et al., 2011) and because reduced p 75 levels may affect the efficiency of retrograde NGF-dependent dendrite growth. Nontranscriptional effects by LIMK1 and JNK activation may also contribute to dendrite growth of sympathetic neurons as shown for BMP-induced dendrite growth in cultured cortical neurons (Lee-Hoeflich et al., 2004; Podkowa et al., 2010).

\section{Local or target-dependent control of dendritic growth}

Target-derived NGF is essential for the elaboration of dendrites, including the formation of postsynaptic specializations, and maintains dendrite morphology up to maturity (Snider, 1988; Ruit et al., 1990; Ruit and Snider, 1991; Sharma et al., 2010). As BMPs are expressed both in target tissues (Ducy and Karsenty, 2000; Pavelock et al., 2007) and in ganglia (Beck et al., 2001; Lein et al., 2002), dendritic growth may be controlled by retrograde signaling and/or locally in the ganglion. BMPs produced by nonneuronal ganglion cells may activate receptors in neuronal cell bodies and interact with retrograde NGF signaling endosomes. On the other hand, retrograde signaling by BMP/TGF $\beta$ family members is widely in effect during vertebrate and invertebrate nervous system development (Eaton and Davis, 2005; Hodge et al., 2007; Ball et al., 2010; Ji and Jaffrey, 2012). Target-derived BMPs have been implicated in the induction of neurotrophic factor dependency in sympathetic neurons (Gomes and Kessler, 2001) and the reduced dendritic growth in the absence of BMPR1 may be explained by impaired retrograde NGF signaling due to decreased p75 levels. As BMPs are involved in the patterning of peripheral targets, a combinatory retrograde function of BMPs and NGF would allow adaptive changes in dendritic growth depending on the size and characteristics of the innervated targets.

\section{References}

Anderson DJ, Carnahan JF, Michelsohn A, Patterson PH (1991) Antibody markers identify a common progenitor to sympathetic neurons and chromaffin cells in vivo and reveal the timing of commitment to neuronal differentiation in the sympathoadrenal lineage. J Neurosci 11:3507-3519. Medline

Ball RW, Warren-Paquin M, Tsurudome K, Liao EH, Elazzouzi F, Cavanagh C, An BS, Wang TT, White JH, Haghighi AP (2010) Retrograde BMP signaling controls synaptic growth at the NMJ by regulating trio expression in motor neurons. Neuron 66:536-549. CrossRef Medline

Beck HN, Drahushuk K, Jacoby DB, Higgins D, Lein PJ (2001) Bone mor- phogenetic protein-5 (BMP-5) promotes dendritic growth in cultured sympathetic neurons. BMC Neuroscience 2:12. CrossRef Medline

Brodski C, Schaubmar A, Dechant G (2002) Opposing functions of GDNF and NGF in the development of cholinergic and noradrenergic sympathetic neurons. Mol Cell Neurosci 19:528-538. CrossRef Medline

Büchmann-Møller S, Miescher I, John N, Krishnan J, Deng CX, Sommer L (2009) Multiple lineage-specific roles of Smad4 during neural crest development. Dev Biol 330:329-338. CrossRef Medline

Callahan T, Young HM, Anderson RB, Enomoto H, Anderson CR (2008) Development of satellite glia in mouse sympathetic ganglia: GDNF and GFRalphal are not essential. Glia 56:1428-1437. CrossRef Medline

Chen HL, Panchision DM (2007) Concise review: bone morphogenetic protein pleiotropism in neural stem cells and their derivatives-alternative pathways, convergent signals. Stem Cells 25:63-68. CrossRef Medline

Chiu CY, Kuo KK, Kuo TL, Lee KT, Cheng KH (2012) The activation of MEK/ERK signaling pathway by bone morphogenetic protein 4 to increase hepatocellular carcinoma cell proliferation and migration. Mol Cancer Res 10:415-427. CrossRef Medline

Darland DC, Nishi R (1998) Activin A and follistatin influence expression of somatostatin in the ciliary ganglion in vivo. Dev Biol 202:293-303. CrossRef Medline

Derynck R, Zhang YE (2003) Smad-dependent and Smad-independent pathways in TGF- $\beta$ family signalling. Nature 425:577-584. CrossRef Medline

Dimou L, Schnell L, Montani L, Duncan C, Simonen M, Schneider R, Liebscher T, Gullo M, Schwab ME (2006) Nogo-A-deficient mice reveal strain-dependent differences in axonal regeneration. J Neurosci 26:55915603. CrossRef Medline

Ducy P, Karsenty G (2000) The family of bone morphogenetic proteins. Kidney Int 57:2207-2214. CrossRef Medline

Eaton BA, Davis GW (2005) LIM Kinasel controls synaptic stability downstream of the type IIBMP receptor. Neuron 47:695-708. CrossRef Medline

Ernsberger U, Patzke H, Rohrer H (1997) The developmental expression of choline acetyltransferase (ChAT) and the neuropeptide VIP in chick sympathetic neurons: evidence for different regulatory events in cholinergic differentiation. Mech Dev 68:115-126. CrossRef Medline

Fenstermaker V, Chen Y, Ghosh A, Yuste R (2004) Regulation of dendritic length and branching by semaphorin 3A. J Neurobiol 58:403-412. CrossRef Medline

Garred MM, Wang MM, Guo X, Harrington CA, Lein PJ (2011) Transcriptional responses of cultures rat sympathetic neurons during BMP-7induced dendritic growth. PLoS One 6:e21754. CrossRef Medline

Gascon E, Dayer AG, Sauvain MO, Potter G, Jenny B, De Roo M, Zgraggen E, Demaurex N, Muller D, Kiss JZ (2006) GABA regulates dendritic growth by stabilizing lamellipodia in newly generated interneurons of the olfactory bulb. J Neurosci 26:12956-12966. CrossRef Medline

Gaudillière B, Konishi Y, de la Iglesia N, Yao GI, Bonni A (2004) A CaMKIINeuroD signaling pathway specifies dendritic morphogenesis. Neuron 41:229-241. CrossRef Medline

Gomes WA, Kessler JA (2001) Msx-2 and p21 mediate the pro-apoptotic but not the antiproliferative effects of BMP4 on cultured sympathetic neuroblasts. Dev Biol 237:212-221. CrossRef Medline

Gonsalvez DG, Cane KN, Landman KA, Enomoto H, Young HM, Anderson CR (2013) Proliferation and cell cycle dynamics in the developing stellate ganglion. J Neurosci 33:5969-5979. CrossRef Medline

Grueber WB, Jan LY, Jan YN (2003) Different levels of the homeodomain protein cut regulate distinct dendrite branching patterns of Drosophila multidendritic neurons. Cell 112:805-818. CrossRef Medline

Guha U, Gomes WA, Samanta J, Gupta M, Rice FL, Kessler JA (2004) Target-derived BMP signaling limits sensory neuron number and the extent of peripheral innervation in vivo. Development 131:1175-1186. CrossRef Medline

Gundersen HJ, Bendtsen TF, Korbo L, Marcussen N, Møller A, Nielsen K, Nyengaard JR, Pakkenberg B, Sørensen FB, Vesterby A, et al. (1988) Some new, simple and efficient stereological methods and their use in pathological research and diagnosis. Apmis 96:379-394. CrossRef Medline

Guo X, Wang XF (2009) Signaling cross-talk between TGF-beta/BMP and other pathways. Cell Res 19:71-88. CrossRef Medline

Guo X, Chandrasekaran V, Lein P, Kaplan PL, Higgins D (1999) Leukemia inhibitory factor and ciliary neurotrophic factor cause dendritic retrac- 
tion in cultured rat sympathetic neurons. J Neurosci 19:2113-2121. Medline

Guo X, Lin Y, Horbinski C, Drahushuk KM, Kim IJ, Kaplan PL, Lein P, Wang T, Higgins D (2001) Dendritic growth induced by BMP-7 requires Smadl and proteasome activity. J Neurobiol 48:120-130. CrossRef Medline

Hand R, Bortone D, Mattar P, Nguyen L, Heng JI, Guerrier S, Boutt E, Peters E, Barnes AP, Parras C, Schuurmans C, Guillemot F, Polleux F (2005) Phosphorylation of Neurogenin 2 specifies the migration properties and the dendritic morphology of pyramidal neurons in the neocortex. Neuron 48:45-62. CrossRef Medline

Higgins D, Lein P, Osterhout D, Johnson MI (1991) Tisue culture of autonomic neurons. In: Culturing nerve cells (Banker G, Goslin K, eds), pp 177-205. Cambridge, Massachusetts: MIP.

Hocking JC, Hehr CL, Chang RY, Johnston J, McFarlane S (2008) TGFbeta ligands promote the initiation of retinal ganglion cell dendrites in vitro and in vivo. Mol Cell Neurosci 37:247-260. CrossRef Medline

Hodge LK, Klassen MP, Han BX, Yiu G, Hurrell J, Howell A, Rousseau G, Lemaigre F, Tessier-Lavigne M, Wang F (2007) Retrograde BMP signaling regulates trigeminal sensory neuron identities and the formation of precise face maps. Neuron 55:572-586. CrossRef Medline

Ji SJ, Jaffrey SR (2012) Intra-axonal translation of SMAD1/5/8 mediates retrograde regulation of trigeminal ganglia subtype specification. Neuron 74:95-107. CrossRef Medline

Jun JH, Yoon WJ, Seo SB, Woo KM, Kim GS, Ryoo HM, Baek JH (2010) BMP2-activated Erk/MAP kinase stabilizes Runx2 by increasing p300 levels and histone acetyltransferase activity. J Biol Chem 285:36410-36419. CrossRef Medline

Kang JS, Liu C, Derynck R (2009) New regulatory mechanisms of TGF-beta receptor function. Trends Cell Biol 19:385-394. CrossRef Medline

Kim IJ, Drahushuk KM, Kim WY, Gonsiorek EA, Lein P, Andres DA, Higgins D (2004) Extracellular signal-regulated kinases regulate dendritic growth in rat sympathetic neurons. J Neurosci 24:3304-3312. CrossRef Medline

Lee-Hoeflich ST, Causing CG, Podkowa M, Zhao X, Wrana JL, Attisano L (2004) Activation of LIMK1 by binding to the BMP receptor, BMPRII, regulates BMP-dependent dendritogenesis. EMBO J 23:4792-4801. CrossRef Medline

Lein P, Johnson M, Guo X, Rueger D, Higgins D (1995) Osteogenic protein-1 induces dendritic growth in rat sympathetic neurons. Neuron 15:597-605. CrossRef Medline

Lein PJ, Beck HN, Chandrasekaran V, Gallagher PJ, Chen HL, Lin Y, Guo X, Kaplan PL, Tiedge H, Higgins D (2002) Glia induce dendritic growth in cultured sympathetic neurons by modulating the balance between bone morphogenetic proteins (BMPs) and BMP antagonists. J Neurosci 22: 10377-10387. Medline

Lein PJ, Guo X, Shi GX, Moholt-Siebert M, Bruun D, Andres DA (2007) The novel GTPase Rit differentially regulates axonal and dendritic growth. J Neurosci 27:4725-4736. CrossRef Medline

Le Roux P, Behar S, Higgins D, Charette M (1999) OP-1 enhances dendritic growth from cerebral cortical neurons in vitro. Exp Neurol 160:151-163. CrossRef Medline

Liu H, Margiotta JF, Howard MJ (2005) BMP4 supports noradrenergic differentiation by a PKA-dependent mechanism. Dev Biol 286:521-536. CrossRef Medline

Lom B, Cohen-Cory S (1999) Brain-derived neurotrophic factor differentially regulates retinal ganglion cell dendritic and axonal arborization in vivo. J Neurosci 19:9928-9938. Medline

Massagué J, Wotton D (2000) Transcriptional control by the TGF- $\beta / S m a d$ signaling system. EMBO J 19:1745-1754. CrossRef Medline

McAllister AK, Katz LC, Lo DC (1997) Opposing roles for endogenous BDNF and NT-3 in regulating cortical dendritic growth. Neuron 18:767778. CrossRef Medline

McPherson CE, Varley JE, Maxwell GD (2000) Expression and regulation of type IBMP receptors during early avian sympathetic ganglion development. Dev Biol 221:220-232. CrossRef Medline

Mishina Y, Hanks MC, Miura S, Tallquist MD, Behringer RR (2002) Generation of Bmpr/Alk3 conditional knockout mice. Genesis 32:69-72. CrossRef Medline

Morikawa Y, Zehir A, Maska E, Deng C, Schneider MD, Mishina Y, Cserjesi P (2009) BMP signaling regulates sympathetic nervous system develop- ment through Smad4-dependent and -independent pathways. Development 136:3575-3584. CrossRef Medline

Moustakas A, Heldin CH (2005) Non-Smad TGF-beta signals. J Cell Sci 118:3573-3584. CrossRef Medline

Otten U, Schwab M, Gagnon C, Thoenen H (1977) Selective induction of tyrosine hydroxylase and dopamine b-hydroxylase by nerve growth factor: comparison between adrenal medulla and sympathetic ganglia of adult and newborn rats. Brain Res 133:291-303. CrossRef Medline

Pace CJ, Tieman DG, Tieman SB (2002) Intracellular injection in fixed slices: obtaining complete dendritic arbors of large cells. J Neurosci Methods 119:23-30. CrossRef Medline

Parlato R, Otto C, Begus Y, Stotz S, Schütz G (2007) Specific ablation of the transcription factor CREB in sympathetic neurons surprisingly protects against developmentally regulated apoptosis. Development 134:16631670. CrossRef Medline

Pavelock KA, Girard BM, Schutz KC, Braas KM, May V (2007) Bone morphogenetic protein down-regulation of neuronal pituitary adenylate cyclase-activating polypeptide and reciprocal effects on vasoactive intestinal peptide expression. J Neurochem 100:603-616. CrossRef Medline

Perron JC, Dodd J (2009) ActRIIA and BMPRII type II BMP receptor subunits selectively required for Smad4-independent BMP7-evoked chemotaxis. PLoS One 4:e8198. CrossRef Medline

Pfaffl MW, Horgan GW, Dempfle L (2002) Relative expression software tool (REST) for group-wise comparison and statistical analysis of relative expression results in real-time PCR. Nucleic Acids Res 30:e36. CrossRef Medline

Podkowa M, Zhao X, Chow CW, Coffey ET, Davis RJ, Attisano L (2010) Microtubule stabilization by bone morphogenetic protein receptormediated scaffolding of c-Jun $\mathrm{N}$-terminal kinase promotes dendrite formation. Mol Cell Biol 30:2241-2250. CrossRef Medline

Purves D, Voyvodic JT, Magrassi L, Yawo H (1987) Nerve terminal remodeling visualized in living mice by repeated examination of the same neuron. Science 238:1122-1126. CrossRef Medline

Reissmann E, Ernsberger U, Francis-West PH, Rueger D, Brickell PM, Rohrer $H$ (1996) Involvement of bone morphogenetic proteins-4 and-7 in the specification of the adrenergic phenotype in developing sympathetic neurons. Development 122:2079-2088. Medline

Rosso SB, Sussman D, Wynshaw-Boris A, Salinas PC (2005) Wnt signaling through Dishevelled, Rac and JNK regulates dendritic development. Nat Neurosci 8:34-42. CrossRef Medline

Rubin E (1985) Development of the rat superior cervical ganglion: ganglion cell maturation. J Neurosci 5:673-684. Medline

Ruit KG, Snider WD (1991) Administration or deprivation of nerve growth factor during development permanently alters neuronal geometry. J Comp Neurol 314:106-113. CrossRef Medline

Ruit KG, Osborne PA, Schmidt RE, Johnson EM Jr, Snider WD (1990) Nerve growth factor regulates sympathetic ganglion cell morphology and survival in the adult mouse. J Neurosci 10:2412-2419. Medline

Schneider C, Wicht H, Enderich J, Wegner M, Rohrer H (1999) Bone morphogenetic proteins are required in vivo for the generation of sympathetic neurons. Neuron 24:861-870. CrossRef Medline

Shah NM, Groves AK, Anderson DJ (1996) Alternative neural crest cell fates are instructively promoted by TGF $\beta$ superfamily members. Cell $85: 331-$ 343. CrossRef Medline

Sharma N, Deppmann CD, Harrington AW, St Hillaire C, Chen ZY, Lee FS, Ginty DD (2010) Long-distance control of synapse assembly by targetderived NGF. Neuron 67:422-434. CrossRef Medline

Sieber C, Kopf J, Hiepen C, Knaus P (2009) Recent advances in BMP receptor signaling. Cytokine Growth Factor Rev 20:343-355. CrossRef Medline

Snider WD (1988) Nerve growth factor enhances dendritic arborization of sympathetic ganglion cells in developing mammals. J Neurosci 8:26282634. Medline

Stanke M, Junghans D, Geissen M, Goridis C, Ernsberger U, Rohrer H (1999) The Phox2 homeodomain proteins are sufficient to promote the development of sympathetic neurons. Development 126:4087-4094. Medline

Stanke M, Duong CV, Pape M, Geissen M, Burbach G, Deller T, Gascan H, Otto C, Parlato R, Schütz G, Rohrer H (2006) Target-dependent specification of the neurotransmitter phenotype: cholinergic differentiation of sympathetic neurons is mediated in vivo by gp130 signaling. Development 133:141-150. CrossRef Medline

Teitelman G, Baker H, Joh TH, Reis DJ (1979) Appearance of catecholaminesynthesizing enzymes during development of rat sympathetic nervous 
system: possible role of tissue environment. Proc Natl Acad Sci U S A 76:509513. CrossRef Medline

ten Dijke P, Hill CS (2004) New insights into TGF- $\beta$-Smad signalling. Trends Biochem Sci 29:265-273. CrossRef Medline

Tsarovina K, Pattyn A, Stubbusch J, Müller F, van der Wees J, Schneider C, Brunet JF, Rohrer H (2004) Essential role of Gata transcription factors in sympathetic neuron development. Development 131:47754786. CrossRef Medline

Tsarovina K, Reiff T, Stubbusch J, Kurek D, Grosveld FG, Parlato R, Schütz G, Rohrer H (2010) The Gata3 transcription factor is required for the survival of embryonic and adult sympathetic neurons. J Neurosci 30:1083310843. CrossRef Medline

Varley JE, Maxwell GD (1996) BMP-2 and BMP-4, but not BMP-6, increase the number of adrenergic cells which develop in quail trunk neural crest cultures. Exp Neurol 140:84-94. CrossRef Medline

Voyvodic JT (1987) Development and regulation of dendrites in the rat superior cervical ganglion. J Neurosci 7:904-912. Medline

Voyvodic JT (1989) Peripheral target regulation of dendritic geometry in the rat superior cervical ganglion. J Neurosci 9:1997-2010. Medline

Wearne SL, Rodriguez A, Ehlenberger DB, Rocher AB, Henderson SC, Hof PR (2005) New techniques for imaging, digitization and analysis of three-dimensional neural morphology on multiple scales. Neuroscience 136:661-680. CrossRef Medline
Withers GS, Higgins D, Charette M, Banker G (2000) Bone morphogenetic protein-7 enhances dendritic growth and receptivity to innervation in cultured hippocampal neurons. Eur J Neurosci 12:106-116. CrossRef Medline

Xu X, Han J, Ito Y, Bringas P Jr, Deng C, Chai Y (2008) Ectodermal Smad4 and p38 MAPK are functionally redundant in mediating TGFbeta/BMP signaling during tooth and palate development. Dev Cell 15:322-329. CrossRef Medline

Yang X, Li C, Herrera PL, Deng CX (2002) Generation of Smad4/Dpc4 conditional knockout mice. Genesis 32:80-81. CrossRef Medline

Yawo H (1987) Changes in the dendritic geometry of mouse superior cervical ganglion cells following postganglionic axotomy. J Neurosci 7:3703-3711. Medline

Yi SE, Daluiski A, Pederson R, Rosen V, Lyons KM (2000) The type I BMP receptor BMPRIB is required for chondrogenesis in the mouse limb. Development 127:621-630. Medline

Yu X, Malenka RC (2003) Beta-catenin is critical for dendritic morphogenesis. Nat Neurosci 6:1169-1177. CrossRef Medline

Zhang D, Mehler MF, Song Q, Kessler JA (1998) Development of bone morphogenetic protein receptors in the nervous system and possible roles in regulating trkC expression. J Neurosci 18:3314-3326. Medline

Zhang YE (2009) Non-Smad pathways in TGF-beta signaling. Cell Res 19: 128-139. CrossRef Medline 